\title{
BATAL \\ The Balloon Measurement Campaigns of the Asian Tropopause Aerosol Layer
}

J.-P. Vernier, T. D. Fairlie, T. Deshler, M. Venkat Ratnam, H. Gadhavi, B. S. Kumar, M. Natarajan, A. K. Pandit, S. T. Akhil Raj, A. Hemanth Kumar, A. Jayaraman, A. K. Singh, N. Rastogl, P. R. Sinha, S. Kumar, S. Timari, T. Wegner, N. Baker, D. Vignelles, G. Stenchikov, I. Shevchenko, J. Smith, K. Bedka, A. Kesarkar, V. Singh, J. Bhate, V. Ravikiran, M. Durga Rao, S. Ravindrababu, A. Patel, H. Vernier, F. G. Wienhold, H. liu, T. N. Knepp, L. Thomason, J. Crawford, L. Ziemba, J. Moore, S. Crumeyrolle, M. Williamson, G. Berthet, F. Jégou, and J.-B. Renard

\begin{abstract}
A series of NASA-ISRO-sponsored balloon campaigns in India and Saudi Arabia was conducted between 2014 and 2017 to study the nature, formation, and transport of polluted aerosols in the upper troposphere and lower stratosphere during the Asian summer monsoon.
\end{abstract}

A sian pollution sources and their strength have changed over the last few decades. Recent satellite observations have shown that the highest nitrogen dioxide $\left(\mathrm{NO}_{2}\right)$ and sulfur dioxide $\left(\mathrm{SO}_{2}\right)$ emissions have shifted from China to India (Krotkov et al. 2016). China's $\mathrm{SO}_{2}$ emissions have decreased by $50 \%$ after the installation of desulfurization systems in their power plants, while $\mathrm{SO}_{2}$ emissions in India have doubled between 2005 and 2015 (Krotkov et al. 2016). The shift in the highest $\mathrm{SO}_{2}$ emissions toward the tropics could have serious implications for their redistribution in the atmosphere. During the Asian summer monsoon (ASM), tropical convective systems provide a vertical transport pathway for boundary layer pollutants to reach the tropical tropopause layer (TTL), which is a gateway to the global stratosphere. Sulfur dioxide and other gas-phase precursors transported into the TTL can be converted into sulfuric acid droplets and other aerosols with consequences for the radiative balance, stratospheric ozone chemistry, and properties of cirrus clouds near the tropopause (Kremser et al. 2016).

Satellite observations have revealed the presence of pollution markers [e.g., carbon monoxide (CO), hydrogen cyanide $(\mathrm{HCN})$, and methane $\left.\left(\mathrm{CH}_{4}\right)\right]$ in the upper troposphere and lower stratosphere
(UTLS) region during the ASM (Randel and Park 2006; Park et al. 2007; Randel et al. 2010). Together with model simulations (e.g., Lawrence and Lelieveld 2010), these studies suggest that deep convection can serve as a conduit for the transport of gas-phase boundary layer pollutants to the UTLS. Pollutants can accumulate in the UTLS under anticyclonic flow conditions (the Asian anticyclone) that characterize the UTLS between the eastern Mediterranean Sea and China during the ASM, and which encompasses northern India. Figure 1 shows a sketch of the transport mechanisms associated with the ASM. An overpass of the Cloud-Aerosol Lidar and Infrared Pathfinder Satellite Observations (CALIPSO) satellite for 12 August 2017 shows the vertical extension of convective storms reaching the UTLS over India. Air transported via the ASM anticyclone to the tropical upper troposphere can reach the lower stratosphere via relatively slow diabatic ascent (Garny and Randel 2016). In addition, strong mesoscale convective systems (MCSs) in India can directly penetrate the lower stratosphere. Detrainment of air from the anticyclone due to transience in the flanking jet streams, in particular, Rossby wave breaking along the subtropical jet, can lead to an irreversible exchange of air with the extratropical lower stratosphere (Vogel et al. 
2016), with implications for the lower-stratospheric composition throughout the hemisphere.

In addition to trace gases, aerosol concentrations are enhanced in the UTLS during the ASM. CALIPSO satellite observations have shown a recurrent aerosol layer in clear-sky summertime backscatter profiles near $13-18 \mathrm{~km}$ from the eastern Mediterranean Sea to western China and India (Vernier et al. 2011,

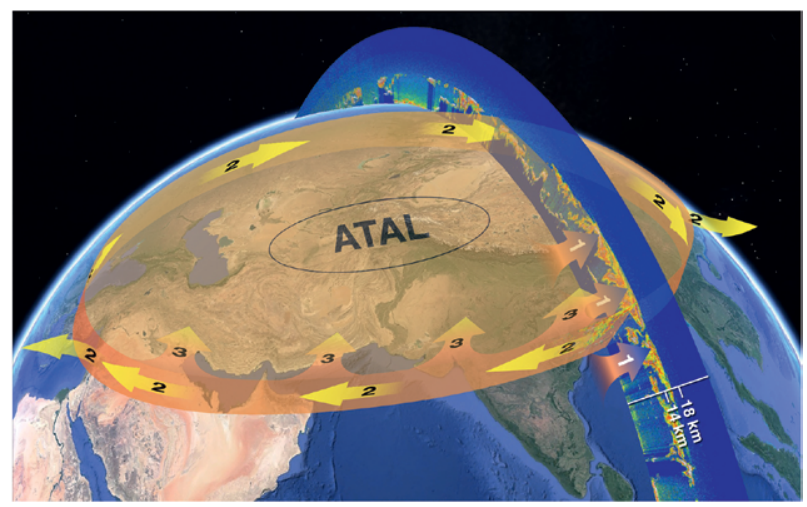

FIG. I. Deep convection from the ASM transports air masses from the boundary layer to the UTLS (feature I). An overpass of the CALIPSO lidar at 1930 UTC I2 Aug 2017 shows the vertical extension of convection through backscatter measurements. The monsoonal outflow is transported through tropical easterlies prevailing in the UTLS along the southern branch of the Asian anticyclone (feature 2). Air in the tropical upper troposphere along the southern edge of the Asian anticyclone can be uplifted into the lower stratosphere via diabatic ascent (feature 3). The ATAL is a pool of aerosols filling the Asian anticyclone shown as a light yellowish color.
2015), called the Asian tropopause aerosol layer (ATAL). The ATAL was confirmed through solar occultation observations by Stratospheric Aerosol and Gas Experiment (SAGE) II (Thomason and Vernier 2013) after improving the cloud-aerosol separation approach using the ratio between aerosol extinction coefficients retrieved at two wavelengths. Analysis of long-term satellite measurements of UTLS aerosols suggests that ATAL's aerosol optical depth has increased by $2-3$ times since the late 1990 s, pointing out its possible connection with Asian pollution growth (Vernier et al. 2015). Satellite observations of ATAL are consistent with early measurements carried out from the Tibetan Plateau during the late 1990s. Ground-based lidar in Lhasa, Tibet, showed the presence of an aerosol layer between 14 and $19 \mathrm{~km}$ with a scattering ratio (SR) $=1.1-1.2$ and $\delta<5 \%$ (Kim et al. 2003). In addition, balloon measurements at the same location in August 1999 have shown an enhancement of small particles of effective radius $r<0.6 \mu$ m near the tropopause (Tobo et al. 2007). More recently, in situ backscatter measurements using the Compact Optical Backscatter Aerosol Detector (COBALD) and aerosol size distribution from the Printed Optical Particle Spectrometer (POPS) have confirmed the presence of the ATAL (Vernier et al. 2015; Yu et al. 2017).

The presence of aerosol near the tropopause could impact the Earth's radiative balance and the properties of cirrus clouds. The direct summertime radiative forcing resulting from the aerosol optical depth (AOD) increase of the ATAL, since the late 1990 s, was estimated near $-0.1 \mathrm{~W} \mathrm{~m}^{-2}$ using radiative
AfFiliations: J.-P. Vernier,* KNePP, AND MOORE-Science Systems and Applications, Inc., Lanham, Maryland, and NASA Langley Research Center, Hampton, Virginia; FaIRLIE, NAtARAjan, Wegner, Baker, Bedka, Thomason, Crawford, and Ziemba-NASA Langley Research Center, Hampton, Virginia; DESHLER-University of Wyoming, Laramie, Wyoming; Venkat Ratnam, Gadhavi, ${ }^{+}$ Pandit, ${ }^{+}$Akhil Raj, A. H. Kumar, Jayaraman, Kesarkar, V. Singh, Bhate, RaVikiran, RaO, and RaVIndRababu—National Atmospheric Research Laboratory, Gadanki, India; Su. KUMAR AND SINHA-Tata Institute of Fundamental Research Balloon Facility, Hyderabad, India; Sa. KUmar, ${ }^{+}$A. K. SINGH, AND TIWARI-Banaras Hindu University, Varanasi, India; RAStOGI AND PATEL-Physical Research Laboratory, Ahmedabad, India; VIGNeLLes, BERTHET, JÉGOU, AND RENARD-LPC2E, Université d' Orléans, CNRS, Orléans, France; STENCHIKOV AND SHEVCHENKO-King Abdullah University of Science and Technology, Thuwal, Saudi Arabia; SMITH AND WILLIAMSONSmith and Williamson, Inc., Corvallis, Oregon; H. VERNIER-Virginia Institute of Marine Science, Gloucester Point, Virginia; WIENHOLDSwiss Federal Institute of Technology, Zurich, Switzerland;
LIU-National Institute of Aerospace, Hampton, Virginia; CrumeYrolle-LOA, CNRS-Université Lillel, Villeneuve d'Ascq, France

*CURRENT AFFILIATION: Vernier-National Institute of Aerospace, Hampton, Virginia +ADDITIONAL AFFILIATIONS: GAdHAVI AND PANDITPhysical Research Laboratory, Ahmedabad, India; S. KUMARAryabhatta Research Institute of Observational Sciences, Nainital, India CORRESPONDING AUTHOR: Jean-Paul Vernier, jeanpaul.vernier@nasa.gov

The abstract for this article can be found in this issue, following the table of contents.

DOI:10.II75/BAMS-D-17-0014.I

In final form 29 November 2017 C2018 American Meteorological Society For information regarding reuse of this content and general copyright information, consult the AMS Copyright Policy. 
parameters corresponding to sulfate aerosol. This represents one-third of the total radiative forcing due to increased $\mathrm{CO}_{2}$ over the same period (Vernier et al. 2015). Thus, the ATAL appears to be a significant player in the Earth's radiative budget of the Northern Hemisphere at decadal scale. Aerosol near the tropopause can potentially affect stratospheric ozone. Solomon et al. (2016) suggested that heterogeneous chlorine chemistry occurring on aerosol in the lower stratosphere during the ASM could impact the local budget and long-term trend of ozone in the UTLS. Finally, the presence of aerosol near the tropopause can potentially alter the properties of TTL cirrus clouds. Pandit et al. (2015) showed that the frequency of subvisible cirrus (SVC) in south India has increased by $9 \%$ from 1998 to 2013, with possible connections with the positive trend in ATAL's AOD since the late 1990s (Vernier et al. 2015).

Since 2014, we have organized a series of balloon field campaigns in India and Saudi Arabia during the ASM to better understand the nature, formation, and impacts of the ATAL. We chose three balloon sites in India to sample air masses directly influenced by convection and to capture the horizontal gradient of aerosol in the UTLS region from the edge to the center of the ASM anticyclone. The location in Saudi Arabia was selected for measurements downwind from the
THE BATAL CAMPAIGNS SPECIFICALLY ADDRESS THE FOLLOWING SCIENCE OUESTIONS:

I) What are the optical properties, size distribution, and composition of the ATAL?

2) How do ozone and water vapor behave near the ATAL?

3) How does convection affect the ATAL?

monsoon region and to study the evolution of air masses along their transport.

\section{DESCRIPTION OF THE BATAL CAM-}

PAIGNS. The Balloon Measurements of the Asian Tropopause Aerosol Layer (BATAL) campaigns have comprised a total of $\sim 68$ balloon flights between 2014 and 2017 from India and Saudi Arabia, with payload weights ranging from 1.5 to $50 \mathrm{~kg}$. The effort has involved a number of institutes from the United States [Science Systems and Applications, Inc., National Aeronautics and Space Administration (NASA) Langley Research Center, and the University of Wyoming], France [Laboratoire de Physique et Chimie de l'Environnement et de l'Espace (LPC2E) Centre National de la Recherche Scientifique

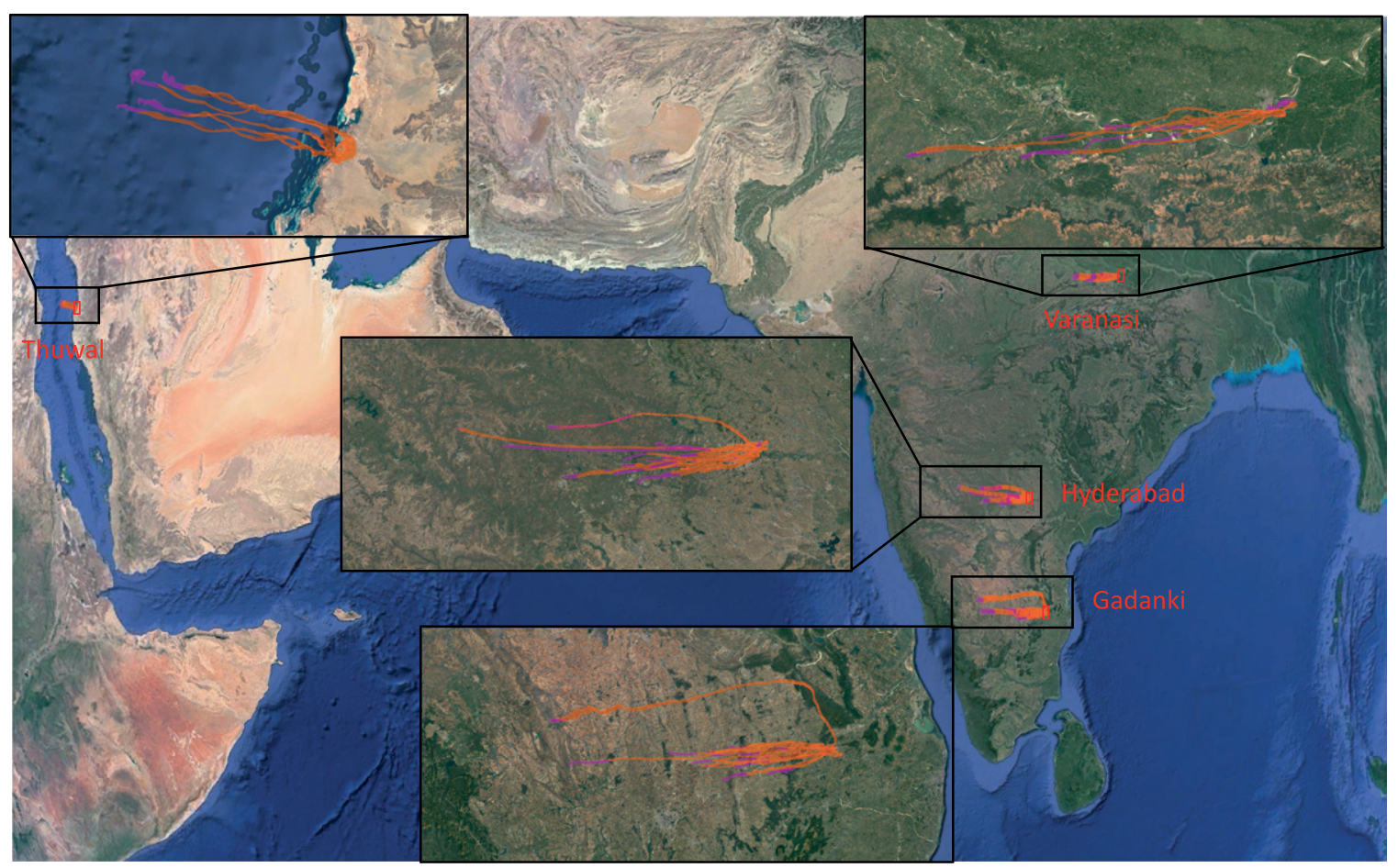

FIG. 2. Balloon trajectories from Gadanki $\left(13.46^{\circ} \mathrm{N}, 79.17^{\circ} \mathrm{E}\right)$, Hyderabad $\left(17.47^{\circ} \mathrm{N}, 78.58^{\circ} \mathrm{E}\right), \mathrm{Varanasi}^{\circ}$ $\left(25.27^{\circ} \mathrm{N}, 82.99^{\circ} \mathrm{E}\right)$, and Thuwal $\left(22.32^{\circ} \mathrm{N}, 39.10^{\circ} \mathrm{E}\right)$ during the BATAL campaigns between 2014 and 2017. The ascending and descending balloon profiles are shown in orange and magenta, respectively. 
(CNRS)/University of Orléans], Switzerland (Swiss Federal Institute of Technology), Saudi Arabia [King Abdullah University of Science and Technology (KAUST)], and India [National Atmospheric Research Laboratory (NARL), Tata Institute of Fundamental Research (TIFR), Banaras Hindu University (BHU), and Physical Research Laboratory (PRL)]. Figure 2 shows the position of the launch sites (Gadanki, Hyderabad, and Varanasi, India; and Thuwal, Saudi Arabia) and the trajectories of the balloon flights conducted during the campaigns. Most of the time, the balloons drifted westward in strong easterly winds of up to $40 \mathrm{~m} \mathrm{~s}^{-1}$ near the cold-point tropopause. Most of the payloads launched from India were recovered after landing within $300 \mathrm{~km}$ from the launch site, while most of the balloon flights from Thuwal landed in the Red Sea.

Ballooning during BATAL. We used different balloon platforms (Tables 1 and 2; Fig. 3) over the 4-yr BATAL effort to address the science questions described in the previous section:

- Heavy balloon flight (HF): The characterization of the optical and physical properties of the ATAL is addressed with aerosol payloads on board HFs with total payload weight greater than $30 \mathrm{~kg}$ using $3,000-\mathrm{m}^{3}$ polyethylene balloons. The HFs took

\section{ZF: A NEW CONCEPT FOR TTL MEASUREMENTS}

$\mathrm{T}^{\mathrm{o}}$

o achieve extended flotation in the UTLS, the ZFs included a ballast module to compensate for altitude loss due to extremely cold temperature near the tropopause. Figure 4 shows a sketch of the static launch method (SLM) used for the ZFs at the balloon facility of TIFR. During the launch preparation, the plastic balloon is fully deployed, and the top portion of it is blocked under a small aluminum roller mounted on the top of a trolley for initial balloon inflation. The bottom part of the balloon is connected to the flight train with the parachute, the communication device, and the science payloads. The ballast module, the last element of the flight train, is hooked to a vehicle. Tow balloons (launch balloons of $20-\mathrm{kg}$ lift capacity) are tied to the communication payload to lift the load line into the air. During the inflation of the balloon, adequate tension is taken by moving the vehicle forward or backward. During the launch, the balloon is released first from the roller until the load line becomes vertical. At that time, the anchor nylon rope between the ballast module and vehicle is cut. Immediately after releasing the payload, a telecommand is given to separate the tow balloons.

\section{BOOMERANG}

Doomerang is a radio-controlled balloon system that includes a valve and a ballast module. The valve allows venting of helium gas from inside the balloon, controlling the internal pressure, which reduces the buoyancy force and thus the ascent rate. $A$ ballast module comprises sand, which can be released to make the system lighter, increasing the balloon ascent rate.

place from the TIFR balloon facility, Hyderabad, in August 2015 and 2017. The balloon facility manufactured the balloons and provided the logistical support for the launches and the recovery of the payloads. During those flights, we also studied the behavior of the ozone and water vapor near the ATAL.

- Zero-pressure flight (ZF): The chemical composition of the ATAL has been studied using an aerosol impactor on board balloon flights floating near the tropopause for several hours, called ZFs (See Fig. 4 and the box at the bottom of the left column for additional information about ZFs). The float duration was critical to collect a sufficient concentration of aerosols on the filters mounted on the aerosol impactor. Filters were sent postflight for ion chromatography (IC) analysis. Four ZFs have been conducted from TIFR since 2015. The time evolution of the GPS altitude of those flights is shown in Fig. 5. The first flight (ZF0) in 2015 did not have a ballast module, and the floating duration between 14 and $18 \mathrm{~km}$ was only $50 \mathrm{~min}$. In 2017, we conducted three additional balloon flights, and each one of them included a ballast module. The maximum floating duration above $14 \mathrm{~km}$ of $2 \mathrm{~h} 50 \mathrm{~min}$ was achieved during ZF3.

- Light flight/medium flight (LF/MF): The optical properties of the ATAL were studied using a backscatter sonde, called COBALD, flown under a meteorological sonde for LFs with 1,200-g latex balloons and a total payload weight of less than $1.3 \mathrm{~kg}$. The MFs included, in addition to LF payloads, ozone and water vapor sensors and sometimes a lightweight aerosol counter to study the size distribution of the ATAL and the chemical composition of the UTLS.

- Boomerang flight (BF): To study the influence of convection on the ATAL, we used a controlled balloon system, developed by Smith and Williamson, Inc., called Boomerang. The rationale was to have a flexible and simple system to launch payloads of less than $10 \mathrm{~kg}$ in weather conditions that would 
not allow for ZF or HF. The goal was to extend the measurement duration in the UTLS region and attempt to fly in convective storms. Boomerang was used with a 3,000-g balloon and a secondary balloon $(1,200 \mathrm{~g})$ to which it was attached with a pressure-sensitive cutdown device. The secondary balloon was cut at a given altitude to rapidly slow down the ascent rate. The two Boomerang flights conducted from Varanasi in August 2016 included an aerosol impactor and COBALD.

\begin{tabular}{|c|c|c|c|}
\hline Flight type & $\begin{array}{l}\text { Approx payload } \\
\text { weight }\end{array}$ & Balloon type & Measurements \\
\hline HF & $>30 \mathrm{~kg}$ & $\mathrm{H}_{2}$ filled, $3,000 \mathrm{~m}^{3}$, polyethylene & $\begin{array}{l}\text { Particle size distribution, volatility, } \\
\text { ozone, water vapor, particle backscatter, } \\
\text { meteorological parameters }\end{array}$ \\
\hline ZF & $>10 \mathrm{~kg}$ & $\mathrm{H}_{2}$ filled, $300 \mathrm{~m}^{3}$, polyethylene & $\begin{array}{l}\text { Extended aerosol measurements near } \\
\text { the tropopause, particle backscatter, } \\
\text { aerosol composition and size } \\
\text { distribution }\end{array}$ \\
\hline MF & $1.3<\mathrm{MF}<10 \mathrm{~kg}$ & $\mathrm{H}_{2}$ filled, $2,000 / 3,000 \mathrm{~g}$, latex & $\begin{array}{l}\text { Combined particle backscatter, ozone, } \\
\text { water vapor, particle size distribution }\end{array}$ \\
\hline LF & $<1.3 \mathrm{~kg}$ & $\mathrm{H}_{2}$ filled, I, $200 \mathrm{~g}$, latex & $\begin{array}{l}\text { Particle backscatter, meteorological } \\
\text { parameters }\end{array}$ \\
\hline $\mathrm{BF}$ & $<10 \mathrm{~kg}$ & $\begin{array}{l}\mathrm{H}_{2} / \mathrm{He} \text { filled, tandem balloons, } \\
2,000 / \mathrm{l}, 200 \mathrm{~g}\end{array}$ & $\begin{array}{l}\text { Particle sampling using impactor with } \\
\text { controlled ascent rate }\end{array}$ \\
\hline
\end{tabular}

TABLE 2. BATAL flights summary. MCPC: mixing condensation particle counter.

\begin{tabular}{|c|c|c|c|}
\hline Campaign & Location & Flights & Payloads \\
\hline \multirow{2}{*}{ BATAL Aug 2014} & \multirow{2}{*}{ Gadanki $\left(13.46^{\circ} \mathrm{N}, 79.17^{\circ} \mathrm{E}\right)$} & $6 \mathrm{LF}$ & \multirow{2}{*}{ iMet, COBALD, Lan OPC } \\
\hline & & I MF & \\
\hline \multirow{2}{*}{ BATAL Jul-Aug 2015} & \multirow{2}{*}{ Gadanki $\left(13.46^{\circ} \mathrm{N}, 79.17^{\circ} \mathrm{E}\right)$} & $4 \mathrm{LF}$ & \multirow{2}{*}{ iMet, COBALD, Lan OPC, CFH, $\mathrm{O}_{3}$} \\
\hline & & $2 \mathrm{MF}$ & \\
\hline \multirow{5}{*}{ BATAL Jul-Aug 2015} & \multirow{5}{*}{ Hyderabad $\left(17.47^{\circ} \mathrm{N}, 78.58^{\circ} \mathrm{E}\right)$} & I LF & \multirow{5}{*}{$\begin{array}{l}\text { iMet, COBALD, CFH, } \mathrm{O}_{3} \text {, Lan OPC, } \\
\text { Wyo OPC,Wyo OPCH,Wyo CN }\end{array}$} \\
\hline & & $6 \mathrm{MF}$ & \\
\hline & & I ZF & \\
\hline & & $2 \mathrm{HF}$ & \\
\hline & & $\mathrm{I} \mathrm{BF}$ & \\
\hline \multirow{3}{*}{ BATAL Jul-Aug 2015} & \multirow{3}{*}{ Varanasi $\left(25.27^{\circ} \mathrm{N}, 82.99^{\circ} \mathrm{E}\right)$} & I LF & \multirow{3}{*}{$\begin{array}{l}\text { iMet, COBALD, CFH, } \mathrm{O}_{3} \text {, Lan OPC, } \\
\text { LOAC, impactor }\end{array}$} \\
\hline & & $5 \mathrm{MF}$ & \\
\hline & & $\mathrm{I} B F$ & \\
\hline BATAL Jul-Aug 2015 & Thuwal $\left(22.32^{\circ} \mathrm{N}, 39.10^{\circ} \mathrm{E}\right)$ & $6 \mathrm{LF}$ & iMet, COBALD \\
\hline \multirow{2}{*}{ BATAL Jul-Aug 2016} & \multirow{2}{*}{ Gadanki $\left(13.46^{\circ} \mathrm{N}, 79.17^{\circ} \mathrm{E}\right)$} & I LF & \multirow{2}{*}{ iMet, COBALD, CFH, $\mathrm{O}_{3}$} \\
\hline & & $4 \mathrm{MF}$ & \\
\hline \multirow{2}{*}{ BATAL Jul-Aug 2016} & \multirow{2}{*}{ Varanasi $\left(25.27^{\circ} \mathrm{N}, 82.99^{\circ} \mathrm{E}\right)$} & $4 \mathrm{MF}$ & \multirow{2}{*}{ iMet, COBALD, $\mathrm{O}_{3}$, Lan OPC, impactor } \\
\hline & & $2 \mathrm{BF}$ & \\
\hline BATAL Jul-Aug 2016 & Thuwal $\left(22.32^{\circ} \mathrm{N}, 39.10^{\circ} \mathrm{E}\right)$ & $5 \mathrm{LF}$ & iMet, COBALD \\
\hline \multirow{2}{*}{ BATAL Jul-Aug 2017} & \multirow{2}{*}{ Gadanki $\left(13.46^{\circ} \mathrm{N}, 79.17^{\circ} \mathrm{E}\right)$} & I LF & \multirow{2}{*}{$\begin{array}{l}\text { iMet, COBALD, } \mathrm{O}_{3} \text {, CFH, Lan OPC, } \\
\text { Meisei CPS }\end{array}$} \\
\hline & & $5 \mathrm{MF}$ & \\
\hline \multirow{3}{*}{ BATAL Jul-Aug 2017} & \multirow{3}{*}{ Hyderabad $\left(17.47^{\circ} \mathrm{N}, 78.58^{\circ} \mathrm{E}\right)$} & $4 \mathrm{MF}$ & \multirow{3}{*}{$\begin{array}{l}\text { iMet, COBALD, } \mathrm{O}_{3} \text {, CFH, Lan OPC, } \\
\text { Boulder OPC, MCPC, impactor }\end{array}$} \\
\hline & & $3 \mathrm{ZF}$ & \\
\hline & & $2 \mathrm{HF}$ & \\
\hline
\end{tabular}


Payloads. To characterize the optical, physical, and chemical properties of the ATAL, we launched payloads specifically designed for aerosol measurements; these included an optically based instrument to measure aerosol backscatter properties (COBALD) and optical particle counters (OPCs) from the University of Wyoming (Wyo), NASA Langley Research Center

\section{Heavy plastic balloon flight}

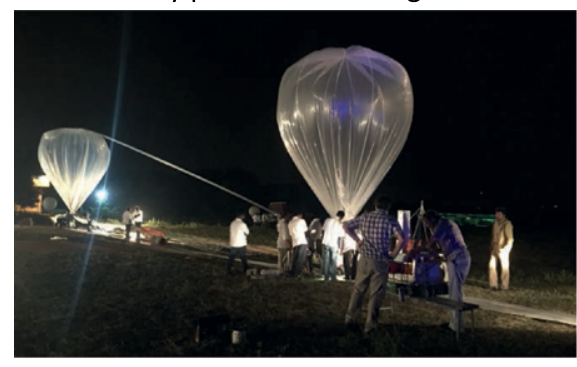

3. Zero pressure flight

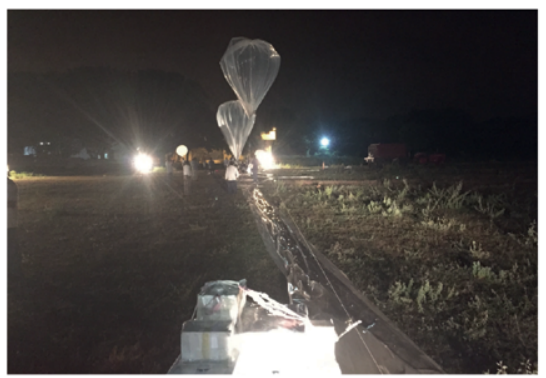

(Lan), and LPC2E for aerosol size distribution and volatility. In addition, we launched an aerosol impactor for composition assessment. Those payloads are further described below and summarized in Table 3.

Aerosol measurements. cobald. COBAld is a lightweight $(540 \mathrm{~g})$ instrument that consists of two high-power light-emitting diodes (LEDs) that emit about $250 \mathrm{~mW}$ of optical power, at wavelengths of 455 and $940 \mathrm{~nm}$, respectively. The backscattered light from the molecules, aerosols, or ice particles is recorded by a silicon photodiode using phase-sensitive detection. The backscatter ratio between aerosols and molecules is inferred from the signal using the radiosonde air pressure and the molecular backscatter. This ratio is not quantified absolutely, but the analysis of the entire sounding profile imposes physical constraints such that it is confined to an absolute error interval of $5 \%$, while precision along the profile is better than $1 \%$ in the UTLS temperature to calculate

FIG. 3. Ballooning during BATAL. Preparation of (top left) HF from Hyderabad using plastic balloons, (top right) regular MF/LF with latex balloons, (bottom left) ZF using plastic balloon, and (bottom right) controlled flight using the Boomerang system attached to the neck of the balloon.

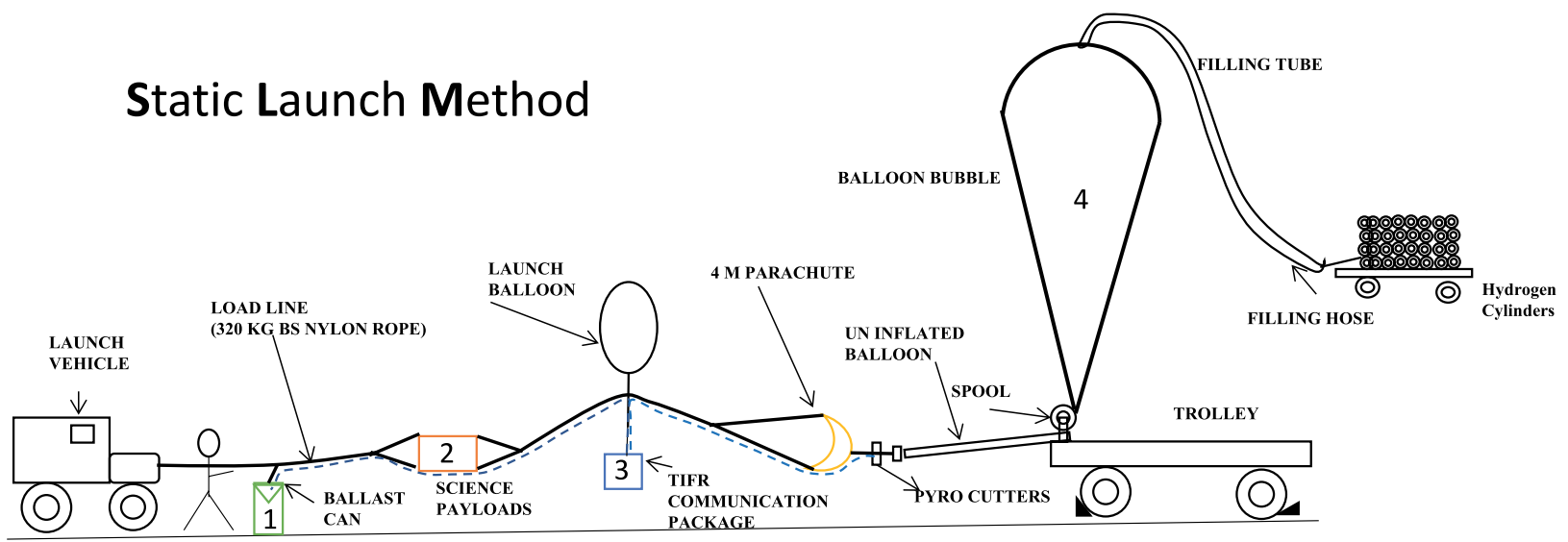

FIG. 4. Sketch of the SLM used during the ZFs at the TIFR balloon facility, Hyderabad. The ballast module holds up to $25 \mathrm{~kg}$ of fine metallic balls, which are released per packet of I $\mathbf{~ k g ~ ( f e a t u r e ~ I ) . ~ T h e ~ s c i e n c e ~ p a y l o a d s ~ i n c l u d e ~}$ an aerosol impactor, a COBALD backscatter sonde, an ozonesonde, and meteorological sondes (feature 2 ). The communication package is used to release ballast on command, terminate the flight through the pyrocutter, and send GPS data through radio communication (feature 3 ). The plastic balloon is filled with hydrogen and has a volume of $300 \mathrm{~m}^{3}$ (feature 4). 
region (Vernier et al. 2015). We use the color index (CI), the ratio between SR-1 at 940 and $455 \mathrm{~nm}$, to eliminate ice clouds in the COBALD data. The COBALD data are usually calibrated in the upper stratosphere above $30 \mathrm{~km}$ in the quasi absence of aerosols.

University of Wyoming OPC. The OPC flown by the University of Wyoming (Deshler et al. 2003) provides vertical profiles of size-resolved aerosol concentration at eight radii between 0.094 and $17 \mu \mathrm{m}$. A second $\mathrm{OPC}$ with an inlet heated to $180^{\circ} \mathrm{C}$ $(\mathrm{OPCH})$ was included to determine the nonvolatile fraction of aerosol concentration. In addition, a condensation nuclei $(\mathrm{CN})$ counter was added to the OPCs to measure the total aerosol number concentration (Campbell and Deshler 2014).

Langley OPC. A small balloonborne OPC payload was developed based upon the adaptation of the Met One
OPC profiler to make aerosol concentration measurement at eight radii between 0.15 to $5 \mu \mathrm{m}$ up to the middle stratosphere. Flow and electronic systems are adapted for balloon flight application, and data are transmitted through an iMet radiosonde.

BAI. To assess the composition of UTLS aerosols, a balloonborne aerosol impactor (BAI) was developed.

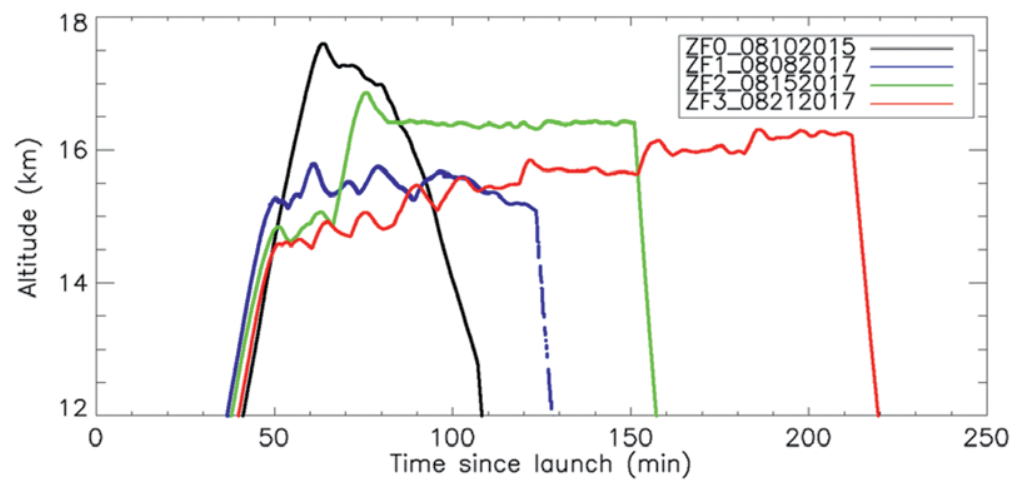

FIG. 5. Time evolution of the GPS altitude four ZFs on 10 Aug 2015 and 8, 15, and 21 Aug 2017.

\begin{tabular}{|c|c|c|c|}
\hline BATAL payloads & Laboratory/company & Measured parameters & Measurement technique \\
\hline iMet radiosonde & iMet & $\begin{array}{l}\text { Temperature, pressure, relative } \\
\text { humidity, wind speed/direction }\end{array}$ & $\begin{array}{l}\text { Piezoresistive, thermistor, } \\
\text { capacitive }\end{array}$ \\
\hline Ozonesonde & $\begin{array}{l}\text { Droplet Measurement Technologies, } \\
\text { United States }\end{array}$ & Ozone concentration & Electrochemical \\
\hline $\mathrm{CFH}$ & $\begin{array}{l}\text { Droplet Measurement Technologies, } \\
\text { United States }\end{array}$ & Water vapor concentration (UTLS) & Chilled-mirror principle \\
\hline $\begin{array}{l}\text { COBALD } \\
\text { backscatter sonde }\end{array}$ & $\begin{array}{l}\text { Eidgenössische Technische } \\
\text { Hochschule (ETH), Switzerland }\end{array}$ & Scattering ratio at 455 and $940 \mathrm{~nm}$ & Light scattering with diodes \\
\hline Lan OPC & $\begin{array}{l}\text { NASA Langley Research Center, } \\
\text { United States }\end{array}$ & $\begin{array}{l}\text { Aerosol concentration } \\
(8 \text { channels, } 0.15-5 \mu \mathrm{m})\end{array}$ & Laser counting \\
\hline Wyo OPC I & $\begin{array}{l}\text { University of Wyoming, } \\
\text { United States }\end{array}$ & $\begin{array}{l}\text { Aerosol concentration } \\
(8 \text { channels, } 0.094-17 \mu \mathrm{m})\end{array}$ & Laser counting \\
\hline Wyo OPCH & $\begin{array}{l}\text { University of Wyoming, } \\
\text { United States }\end{array}$ & $\begin{array}{l}\text { Aerosol concentration } \\
(8 \text { channels, } 0.094-17 \mu \mathrm{m})\end{array}$ & Laser counting \\
\hline Wyo CN counter & $\begin{array}{l}\text { University of Wyoming, } \\
\text { United States }\end{array}$ & $\begin{array}{l}\text { Aerosol concentration } \\
\text { ( } r \text { greater than a few nanometers) }\end{array}$ & $\begin{array}{l}\text { Saturation chamber/optical } \\
\text { counting }\end{array}$ \\
\hline LOAC & LPC2E, France & $\begin{array}{l}\text { Aerosol concentration } \\
(19 \text { channels, } 0.1-50 \mu \mathrm{m})\end{array}$ & Laser counting \\
\hline BAI & $\begin{array}{l}\text { California Measurements- } \\
\text { NASA Langley Research Center, } \\
\text { United States }\end{array}$ & Chemical composition & Aerodynamical impaction \\
\hline Boulder counter & $\begin{array}{l}\text { LightHouse-NASA Langley Research } \\
\text { Center, United States }\end{array}$ & $\begin{array}{l}\text { Ice measurements } \\
(6 \text { channels, } 5-100 \mu \mathrm{m})\end{array}$ & Laser counting \\
\hline $\begin{array}{l}\text { Mixing cloud particle } \\
\text { counter }\end{array}$ & $\begin{array}{l}\text { Bretchel-NASA Langley Research } \\
\text { Center, United States }\end{array}$ & $\begin{array}{l}\text { Aerosol concentration } \\
\text { ( } r \text { greater than a few nanometers) }\end{array}$ & $\begin{array}{l}\text { Saturation chamber/laser } \\
\text { counting }\end{array}$ \\
\hline
\end{tabular}


A ground-based impactor was attached to a scroll pump and controlled by an electronic board based upon meteorological and GPS data from an InterMet Systems Inc. (iMet) radiosonde. The pump was switched on and off at the desired pressure to collect aerosols in a given altitude range. We used a fourstage aerosol impactor from California Measurements with a cutoff radius of $0.025,0.075,0.25$, and $1 \mu \mathrm{m}$ at a flow of $7 \mathrm{~L} \mathrm{~min}^{-1}$.

LOAC. The Light Optical Aerosol Counter (LOAC) is a miniature OPC (Renard et al. 2016). It contains a laser $(650 \mathrm{~nm})$ and measures the intensity of the light scattered at two angles: $12^{\circ}$ and $60^{\circ}$ (Lurton et al. 2014). The particle number concentration (PNC) is provided over 19 size classes from 0.1 to $50 \mu \mathrm{m}$ in radius at a sampling interval of $1 \mathrm{~min}$. Uncertainties are estimated to be of $\pm 30 \%$ for smaller size bins (Renard et al. 2016). In addition to the number concentration, the LOAC gives a specific index relative to the main optical nature of the aerosol sampled, called typology, which is obtained by combining the intensities of light at two scattering angles (Renard et al. 2016). Typology is calibrated in the laboratory with responses given by known samples. Three LOAC OPCs were launched from Varanasi during BATAL 2015. The first two LOAC instruments flown using MF balloons together with a cryogenic frost-point hygrometer (CFH), a Lan OPC, and an ozonesonde did not reach ATAL altitudes. The third LOAC instrument launched in an LF configuration reached the lower stratosphere. No significant enhancement in the aerosol content was detected in the tropopause region, possibly because of the regular losses of telemetry encountered at these altitude levels.

Temperature, PRESSURE, OzONE, AND WATER VAPOR MEASUREMENTS. Ozone and water vapor concentration measurements accompanied aerosol observations on a number of occasions to study the behavior of the ATAL and UTLS chemistry, using an ozonesonde and a $\mathrm{CFH}$, respectively. We used iMet radiosondes on board most of the balloon flights, and occasionally a Meisei radiosonde (RS-11G) to transmit data, follow the balloon trajectory, and obtain the landing location. We included SPOT and global spectral model (GSM)based locators on most of the flights to determine the exact location of the landing and improve the chance of recovery.

Radiosondes. We used Meisei (RS-11G) and iMet radiosondes. These instruments measure temperature from $-90^{\circ}$ to $50^{\circ} \mathrm{C}$ with a resolution of $0.1^{\circ} \mathrm{C}$ and an accuracy of $0.5^{\circ} \mathrm{C}$. Wind speed resolution is $0.1 \mathrm{~m} \mathrm{~s}^{-1}$ with an accuracy of $0.2 \mathrm{~m} \mathrm{~s}^{-1}$. Further details of this radiosonde system, database, and quality checks applied to the data are reported by Venkat Ratnam et al. (2014).

Ozonesondes. We launched electrochemical concentration cell (ECC) ozonesondes (Komhyr et al. 1995) to measure the vertical distribution of ozone from the surface to balloon-burst altitude. The measurement is based on electrochemical oxidation of potassium iodide by ozone in an aqueous solution. The accuracy of the ECC ozonesonde is $\sim 5 \%-10 \%$. More details of the ozonesondes being used at NARL in Gadanki are provided by Akhil Raj et al. (2015).

$\mathrm{CFH}$. The $\mathrm{CFH}$ measures water vapor concentration through the chilled-mirror principle using a cryogenic liquid as a coolant. A small mirror attached at the end of the cold finger piece is electrically heated and cryogenically cooled to maintain a constant thin layer of frost that is optically detected. The mirror temperature is then equal to the ambient dewpoint or frost-point temperature and is measured by a small thermistor embedded in the surface of the mirror. The frost-point temperature is used to calculate the partial pressure of water vapor in air and determine the water vapor mixing ratio (WVMR) with an uncertainty of about $4 \%$ in the lower tropical troposphere to about $10 \%$ in the middle stratosphere and tropical tropopause (Vömel et al. 2007).

\section{Ground-based and modeling support. GROUND-BASED} SUPPORT. Throughout the campaign, at the National Atmospheric Research Laboratory (Gadanki) and the King Abdulah University for Science and Technology (Thuwal), observations were available from additional instrumentations, listed in Table 4 . These include ground-based lidar observations that can be compared with COBALD in situ backscatter measurements from the boundary layer to the middle stratosphere and can be used to validate CALIPSO satellite aerosol retrievals. A current project at KAUST uses COBALD/Aerosol Robotic Network (AERONET) and micropulse lidar (MPL) measurements to help characterize the vertical and temporal structures of dust in the boundary layer. Groundbased lidar measurements from Gadanki are used to characterize the ATAL and subvisible cirrus clouds near the tropopause. In addition, the mesospherestratosphere-troposphere (MST) radar from Gadanki can help assess the influence of convection on the balloon measurements. All ground-based support during 
the BATAL campaigns provided quasi-collocated observations with the balloonborne measurements to better characterize the vertical structure and properties of aerosols and clouds.

MODELING SUPPORT. Throughout the BATAL campaign in India, weather forecasts (http://forecast.narl.gov in/weather) provided by NARL and near-real-time Doppler weather radar images obtained from the India Meteorological Department (www.imd.gov in/section/dwr/dynamic/dwr.htm) supported flight planning for balloon launches.

Starting with the 2017 campaign, regional and global chemical transport simulations have been carried out using the Weather Research and Forecasting (WRF) Model coupled with chemistry (WRF-Chem), version 3.6.1, and the NASA Goddard Earth Observing System (GEOS), version 5 (https:// gmao.gsfc.nasa.gov/forecasts/), with chemical and aerosol forecasts over South Asia.

WRF-Chem was run with a horizontal resolution of $27 \mathrm{~km}$ and 30 vertical levels from the ground to $50 \mathrm{hPa}$. Meteorological initialization and boundary conditions were derived from the National Centers for Environmental Prediction (NCEP) Global Forecast System (GFS) data available every 6-h. Anthropogenic emissions have been obtained from the Hemispheric Transport of Air Pollution Emission Database for Global Atmospheric Research (HTAP-EDGAR), which contains the annual anthropogenic emissions of greenhouse gases and air pollutants at $0.1^{\circ} \times 0.1^{\circ}$ spatial resolution. The simulations have been carried out with the Model for Ozone and Related Chemical Tracers (MOZCART) gas-phase chemistry and Goddard Chemistry Aerosol Radiation and Transport model (GOCART) aerosols.
The GEOS "forward processing" (FP) system generates weather analysis, assimilation products, and 10-day weather and composition forecasts (https://gmao.gsfc.nasa.gov/weather_prediction/). The forecasted fields used for the BATAL campaign included zonal $(U)$ and meridional $(V)$ winds, water vapor, cloud fraction, ozone, $\mathrm{CO}, \mathrm{SO}_{2}$, column aerosol optical depths, and aerosol coefficients. Figure 6 shows maps of $\mathrm{CO}$, sulfate, nitrate, and black carbon (BC) concentrations at $100 \mathrm{hPa}$ for $2100 \mathrm{UTC}$ 3 August 2017, as predicted by NASA GEOS-5 at 0000 UTC 30 July 2017. High levels of CO in the upper troposphere forecasted over Gadanki during BATAL 2017 likely resulted from the convective transport of polluted air from eastern China followed by westward transport along the southern edge of the Asian anticyclone. Sulfate and black carbon aerosol layers were also approaching south India at that time. We used forecasts to make the necessary logistical arrangements and plan balloon flights ahead of time.

SCIENCE HIGHLIGHTS. Characterization of the optical, physical, and chemical properties of the atal. Backscatter measurements from CALIOP AND COBALD. One of the main science objectives of the BATAL campaigns was to characterize the optical properties of the ATAL at multiple locations within the Asian anticyclone through backscatter measurements using the COBALD backscatter sonde and to compare those measurements with the Cloud-Aerosol Lidar with Orthogonal Polarization (CALIOP) on board CALIPSO. Three locations were selected in India to study the aerosol gradient from the southern edge (Gadanki) to the interior (Varanasi) of the Asian anticyclone. In addition, we also chose one site in Saudi Arabia (Thuwal) to sample

TABLE 4. Ground-based measurement support during BATAL.

\begin{tabular}{|llll|}
\hline Location & \multicolumn{1}{c}{ Instruments } & \multicolumn{1}{c|}{ Measured parameters } & $\begin{array}{c}\text { Spatial and temporal } \\
\text { resolutions and mode } \\
\text { of operation }\end{array}$ \\
\hline Gadanki & Indian MST radar & $\begin{array}{l}\text { Turbulence parameters, 3D wind profiles } \\
\text { (zonal, meridional, vertical) }\end{array}$ & $\begin{array}{l}\text { I50 m, I min, continuous } \\
\text { throughout the campaign }\end{array}$ \\
\hline Gadanki & Mie and Rayleigh lidar & Cirrus properties, aerosols, temperature profiles & $\begin{array}{l}300 \mathrm{~m}, 4 \mathrm{~min}, \text { continuous } \\
\text { throughout the campaign }\end{array}$ \\
\hline Gadanki & Lidar for atmospheric & & $30 \mathrm{~m}, \mathrm{I}$ min, continuous \\
& measurement and probing (LAMP) & $\begin{array}{l}\text { Attenuated backscatter signal, aerosol extinction } \\
\text { profile, boundary layer height, cloud-base height, } \\
\text { optical depth for optically thin clouds }\end{array}$ & $\begin{array}{l}\text { Surface, I min, continuous } \\
\text { throughout the campaign }\end{array}$ \\
\hline Gadanki & Surface measurements & $\begin{array}{l}\text { Temperature, relative humidity, wind speed and } \\
\text { direction, rainfall }\end{array}$ & \\
\hline Thuwal & MPL & Attenuated backscatter and depolarization at $532 \mathrm{~nm}$ & \\
\hline Thuwal & AERONET/sun photometer & Radiance and derived aerosol distribution & \\
\hline
\end{tabular}



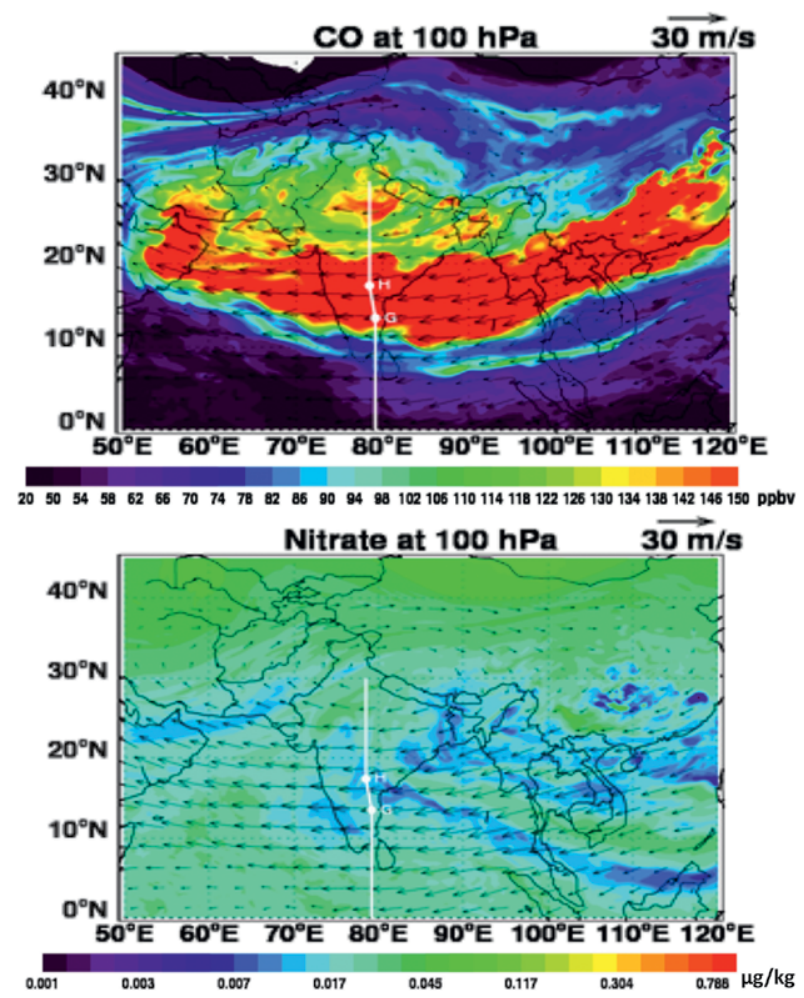
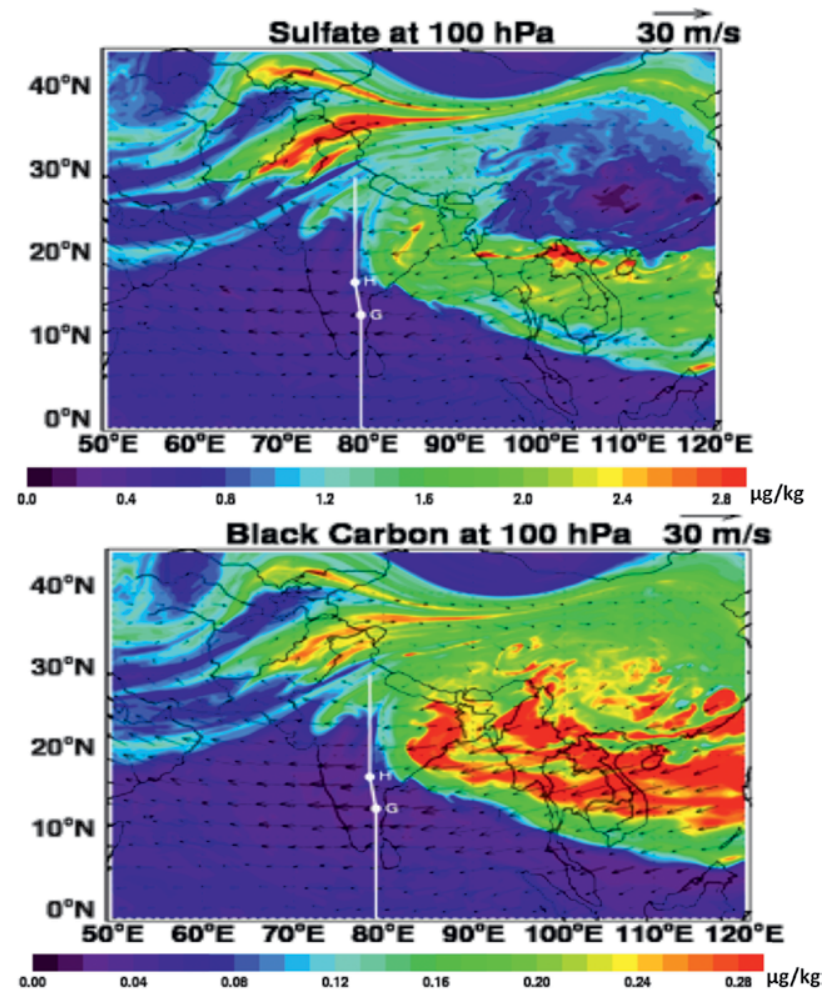

Fig. 6. Concentrations of $C O$, sulfate, nitrate, and $B C$ at $100 \mathrm{hPa}$ at 2100 UTC 3 Aug 2017 , as predicted by the NASA GEOS-5 FP forecasting system at 0000 UTC 30 Jul 2017. Arrows denote winds. White dots along the white line ( $G$ and $H$ ) indicate two balloon sounding locations, Gadanki and Hyderabad, respectively.

the outflow from the Indian monsoon through the westward circulation prevailing in the UTLS. Figure 7 shows a map of SR at $532 \mathrm{~nm}$, optically equivalent to an aerosol mixing ratio, averaged from CALIOP observations acquired between July and August 2015. Corresponding cross sections averaged between $15^{\circ}$ and $45^{\circ} \mathrm{N}$ latitudes (bottom) and between $5^{\circ}$ and $105^{\circ} \mathrm{E}$ longitudes (right) illustrate the $3 \mathrm{D}$ distribution of the UTLS aerosols.

We used version 4 of the CALIOP level 1 data, which are based upon a new calibration scheme of the nighttime profiles between 36 and $39 \mathrm{~km}$ (Vernier et al. 2009). The SR is calculated from the averaged total attenuated backscatter at $532 \mathrm{~nm}$ every $1^{\circ}$ along each orbit track and corrected from ozone absorption and molecular scattering using air density from the NASA GEOS-5 assimilated dataset. The data have been cleared from clouds when at least three of the five consecutive vertical bins have depolarization ratio values greater than $5 \%$ below $20 \mathrm{~km}$. All data below clouds are removed to avoid cloud attenuation effects. Rogers et al. (2011) showed that the error at midlatitudes of the CALIOP data are near 5\% compared to aircraft high-spectral-resolution lidar measurements. We anticipate that the residual error from aerosol contamination in the calibration region of $36-39 \mathrm{~km}$ is near $2 \%$ in the tropics. Thus, the total relative error on the CALIOP SR is expected to be less than $6 \%$.

The ATAL is seen in Fig. 7 through elevated mean SR near $1.13 \pm 0.07$ from the eastern Mediterranean Sea to western China between 360 - and $440-K$ potential temperature surfaces. The aerosol layer is thinner near the equator and about 3-4 $\mathrm{km}$ thick between $30^{\circ}$ and $40^{\circ} \mathrm{N}$.

The CALIOP and corresponding COBALD profiles obtained during the BATAL balloon flights are shown in Fig. 8. We use the CI to eliminate ice clouds in the COBALD data. We relax the threshold on the CI to 10 since the value of 7 proposed by Vernier et al. (2015) seems to remove clear-sky data. After visual inspection, we find that the new filter does not retain subvisible cirrus clouds.

The satellite and in situ measurements agree within $\sim 10 \%$ from 14 and $24 \mathrm{~km}$ for the flights at Gadanki and Hyderabad (Fig. 8, left). The averaged profile from Thuwal (Fig. 8, right) exhibits a larger difference compared to CALIOP, with an apparent offset of 0.03-0.04. The retrievals of COBALD and CALIOP SR profiles are based upon independent calibration procedures that 
CALIPSO-JUL-AUG-15 16-18 km

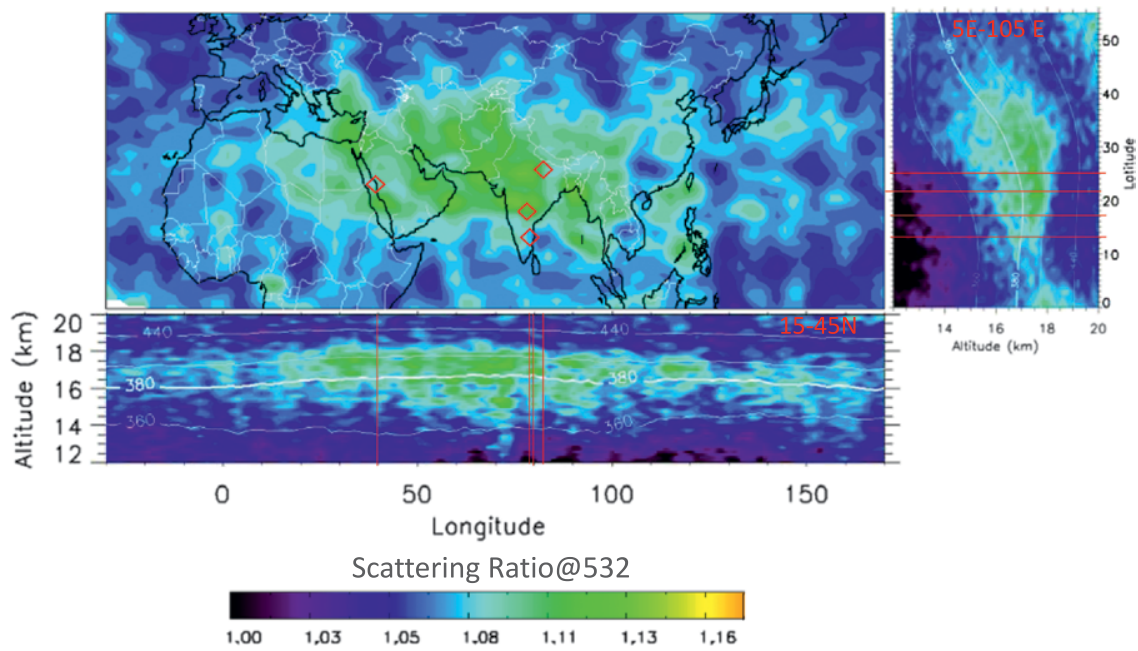

Fig. 7. (top) Map of SR at $532 \mathrm{~nm}$ after averaging the CALIPSO cloud-cleared data between 16 and $18 \mathrm{~km}$ in Jul-Aug 2015. Corresponding cross sections from averaged data between (bottom) $15^{\circ}$ and $45^{\circ} \mathrm{N}$ and (right) $5^{\circ}$ and $105^{\circ} \mathrm{E}$ depict the 3D extension of the ATAL. The white lines show isopleths of potential temperature $(K)$. The locations of the balloon launches during the BATAL deployments are shown by red diamonds on the map and red lines on the cross sections (Gadanki, Hyderabad, Thuwal, and Varanasi).
ADVANCED MICROPHYSICAL PROPERTIES OF THE ATAL. During BATAL 2015, we conducted two heavy balloon flights, carrying $\sim 50 \mathrm{~kg}$ of instrumentation, telecommunication, and recovery systems from the TIFR balloon facility, Hyderabad. These balloons carried two OPCs from the University of Wyoming, one with an ambient inlet and another with an inlet heated to $>180^{\circ} \mathrm{C}$ to derive the aerosol volatility fraction, defined as the difference between total and non-volatile (heated) aerosol number concentrations divided by the total aerosol number concentration. In addition, a CN counter from the University of are usually applied in the upper stratosphere. However, since the bursting altitude of a balloon flight is usually below $34 \mathrm{~km}$, COBALD profiles are referenced below this level, while CALIOP backscatter profiles are calibrated between 36 and $39 \mathrm{~km}$. The COBALD profiles are artificially compensated for the presence of aerosol in the calibration region by multiplying by a correction factor. Differences in the calibration procedure are therefore the likely cause of the differences observed at Thuwal between COBALD and CALIOP.

Nevertheless, the ATAL is seen in both balloon and satellite profiles within the coldest region of the atmosphere between 14 and $19 \mathrm{~km}$. CALIOP observations show the absence of an ATAL during the winter season (Fig. 2; Vernier et al. 2015). Throughout the BATAL campaigns in India, SR maxima were often located near the cold-point tropopause, suggesting the influence of temperature on the processes involved in aerosol formation and/ or growth.
Wyoming was included to derive the concentration of particles with radii greater than $10 \mathrm{~nm}$. Figure 9 shows data from the balloon flight on 13 August. We found a relatively high concentration of aerosol (up to $\sim 25 \mathrm{~cm}^{-3}$ ) near the tropopause $(16-19 \mathrm{~km})$ with $r>0.094 \mu \mathrm{m}$, comparable to those observed in the boundary layer. Particle number concentration for $r>0.15$ and $r>0.30 \mu \mathrm{m}$ is smaller by a factor of 30 and 300 , respectively. The volatility fraction, shows
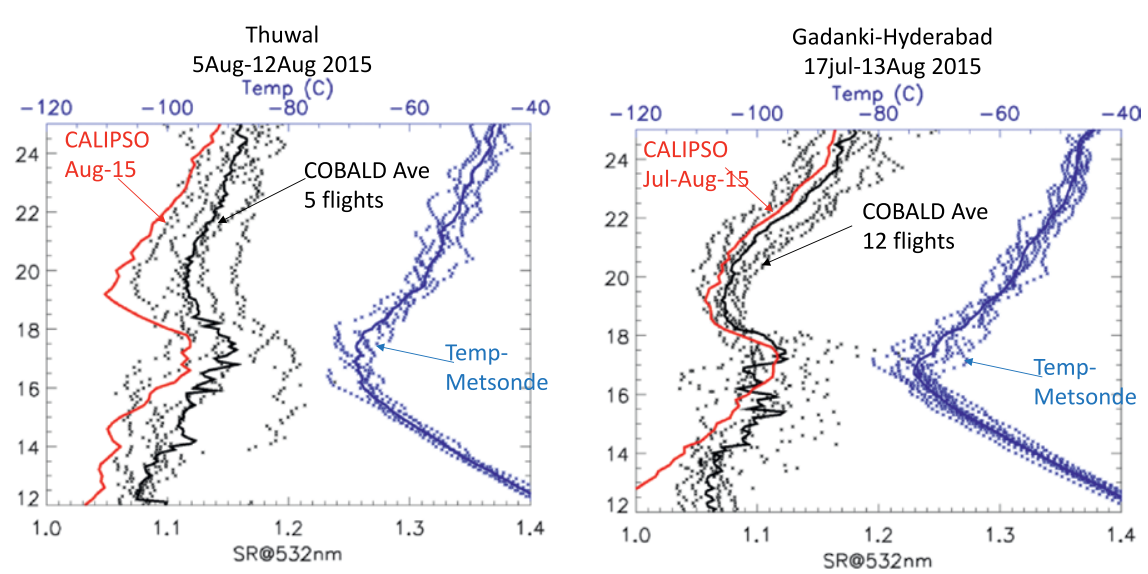

FIG. 8. SR profiles (black stars) at $532 \mathrm{~nm}$ derived from the COBALD balloon flights in (left) Thuwal between 5 and 12 Aug 2015 and (right) GadankiHyderabad between 17 Jul and 13 Aug 20I5. Averaged COBALD profiles (black line) and CALIPSO profiles (red line) within $\pm 5^{\circ}$ latitude and $\pm 30^{\circ}$ longitude are shown. Radiosonde individual (blue stars) and averaged (blue line) temperature profiles are also shown. 
that $80 \%-95 \%$ of these aerosols have a volatile component and are thus likely partially or totally liquid in the $16-18-\mathrm{km}$ altitude range. The volatile fraction of aerosol at $0.094 \mu \mathrm{m}$ is shown in Fig. 9b. The shapes of the total/nonvolatile aerosol concentration profiles are very similar, with a peak near the cold-point tropopause (Fig. 9b), suggesting that aerosols with a nonevaporating (refractive), and thus likely solid, core had been transported at those levels. The $\mathrm{CN}$ measurements were saturated throughout the troposphere and decreased sharply near the tropopause (Fig. 9a).
High aerosol concentrations near the tropopause coincide with a peak in SR $(\sim 17 \mathrm{~km})$ of 1.9 associated with low color index $(\mathrm{CI}<10)$ values measured by COBALD in contrast with ice clouds showing CI near 20 (15-16.5 km; Fig. 9d).

OZONE AND WATER VAPOR BEHAVIOR NEAR THE ATAL. In addition to the aerosol measurements described above, we also flew an ozonesonde and a CFH for ozone and water vapor measurements, respectively. Interestingly, enhanced water vapor (up to 7-8 ppmv) near $17-18 \mathrm{~km}$
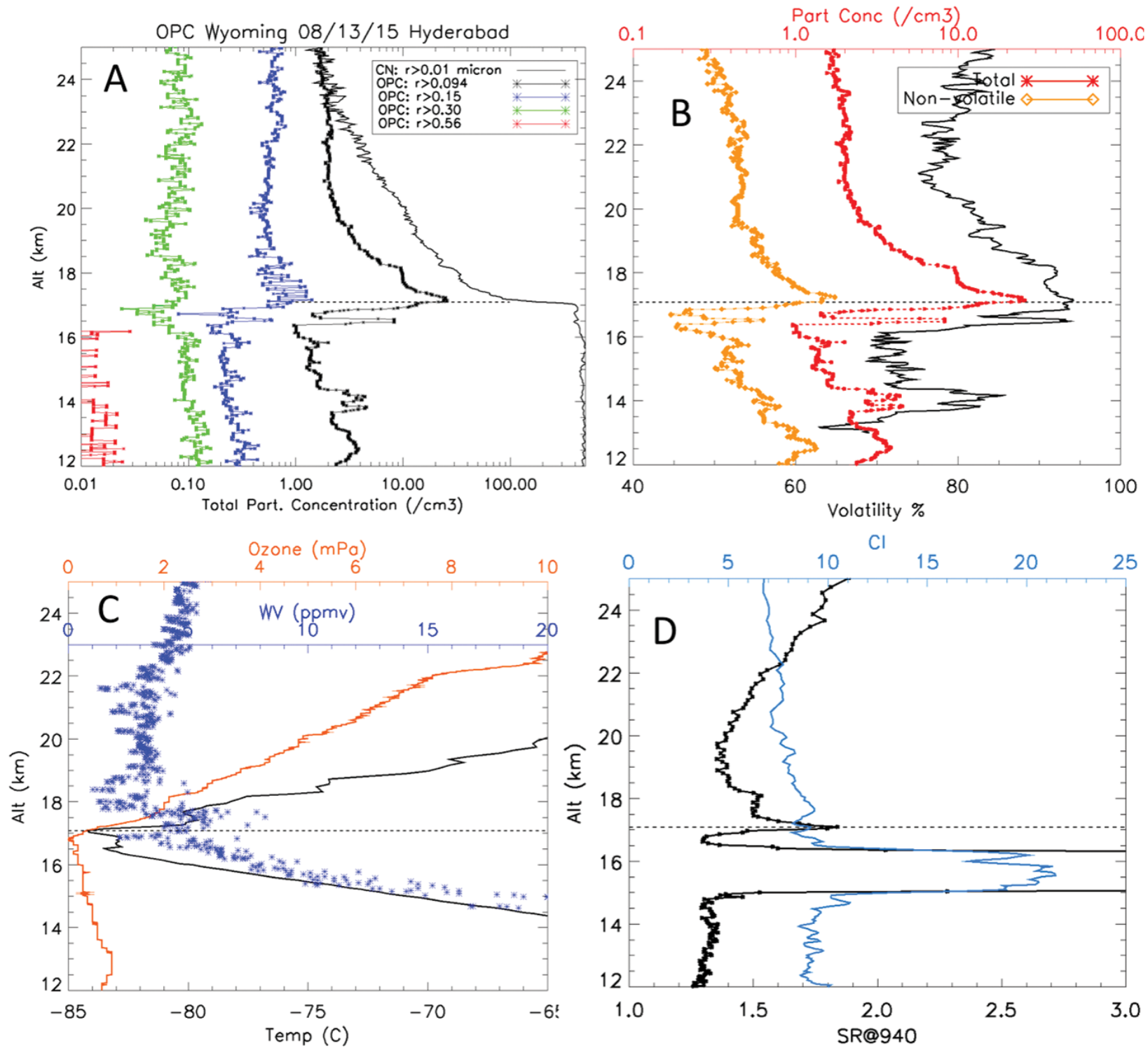

Fig. 9. HF ascent profile of data collected on 13 Aug 2015 from Hyderabad. (a) PNC profiles from unheated OPC for radius: $r>0.094, r>0.15, r>0.30$, and $r>0.56 \mu \mathrm{m}$ and $\mathrm{CN}$ profile from a $\mathrm{CN}$ counter for $r>0.01 \mu \mathrm{m}$. (b) PNC profiles for $r>0.094 \mu \mathrm{m}$ from heated $\left(180^{\circ} \mathrm{C}\right)$ and unheated OPCs. The Volatility \% (in black) is defined as the difference between the total and non-volatile (heated) aerosol number concentrations divided by the total aerosol number concentration (c) Temperature, ozone partial pressure, and WVMR profiles. (d) SR at $940 \mathrm{~nm}$ and $\mathrm{Cl}\left[\mathrm{Cl}=\left(\mathrm{SR}_{940}-\mathrm{I}\right) /\left(\mathrm{SR}_{455}-\mathrm{I}\right)\right]$ profiles from COBALD. 
were observed just above the cold-point tropopause and the peak in aerosol concentration (Figs. 9c,a). The ozone partial pressure profile shown in Fig. 9c displays a sharp increase from 0 to $2 \mathrm{mPa}$ between 17 and $18 \mathrm{~km}$. The presence of a moist layer near the tropopause strongly suggests the influence of convection up to these levels. Deep convection is also known to inject tropospheric air with low ozone concentrations, which could explain the very low ozone values near the cold-point tropopause.

In addition, heterogeneous ozone chemistry in the lower stratosphere could also result in ozone depletion through chlorine activation on aerosol (Solomon et al. 2016). Thus, the behavior of ozone, water vapor, and aerosol can be strongly interrelated via the influence of deep convection.

COMPOSITION OF THE ATAL. To study the composition of the ATAL, we developed a BAI (see "Description of the BATAL campaigns: Payloads" section) to collect size-segregated aerosols on filters near the tropopause and analyze their composition through IC. The BAI flew on three ZFs on 8, 15, and 21 August at TIFR. The pump, connected to a four-stage impactor, was switched on automatically below $150 \mathrm{hPa}(\sim 14 \mathrm{~km})$ and above $70 \mathrm{hPa}(\sim 20 \mathrm{~km})$. To collect sufficient particles on filters, we maximized the floating duration of the balloons near the tropopause using the ZF concept (see "Description of the BATAL campaigns" section). During those flights, the pump was on for $1 \mathrm{~h} 20 \mathrm{~min}$ during ZF1, $1 \mathrm{~h} 47 \mathrm{~min}$ during ZF2, and $2 \mathrm{~h} 47 \mathrm{~min}$ during ZF3. The volume of air passing through the impactor was controlled and calculated with a mass flowmeter. A total volume of 566 and $917 \mathrm{~L}$ of air was sampled during ZF2 and ZF3, respectively. In addition, the BAI was run on the rooftop of the TIFR balloon facility on 23 August for $45 \mathrm{~min}$ to provide a comparison basis for the flight measurements. After three successful ZFs, the BAI was recovered in good condition and brought back to TIFR. The filters were loaded and unloaded from the BAI in a clean room of class 7 and refrigerated at $-24^{\circ} \mathrm{C}$. The filters were transported from TIFR to the Physical Research Laboratory in Ahmedabad, India, by flight using a

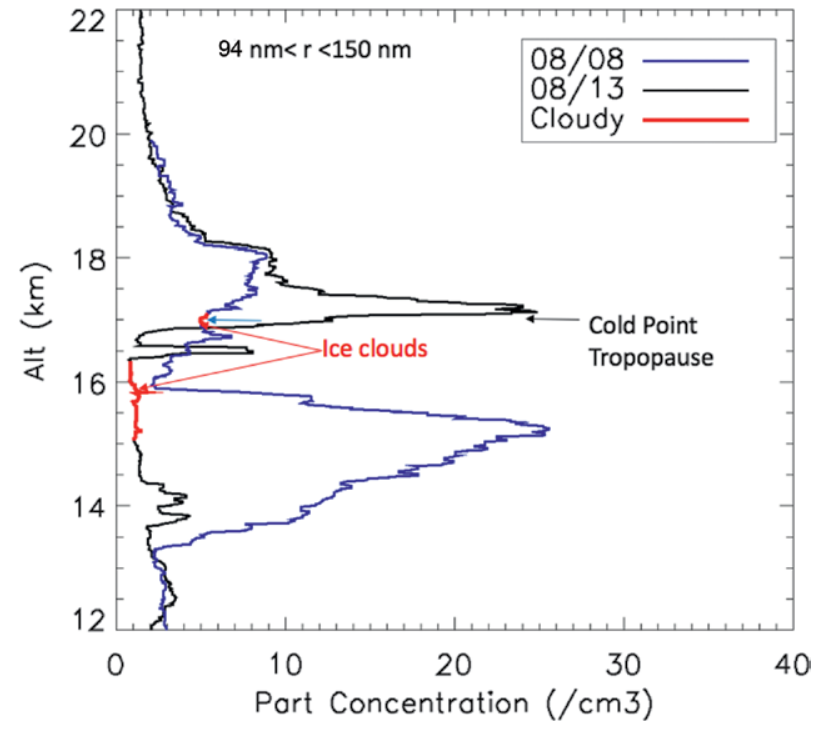

FIG. II. Aerosol concentration profiles for particles within $0.094<r<0.15 \mu \mathrm{m}$ from the $2015 \mathrm{HFs}$ on 8 and 13 Aug in Hyderabad. Part of the profiles where COBALD detected ice clouds based upon the $\mathrm{Cl}$ is colored in red. We note that the $\mathrm{Cl}$ profile below $15 \mathrm{~km}$ on 8 Aug was too noisy to apply the $\mathrm{Cl}$ criteria.

cooler with dry ice to maintain the temperature at freezing levels. Figure 10 shows the concentration of ions measured through IC at the Physical Research Laboratory. We note the presence of nitrate ions with a concentration of about $100 \mathrm{ng} \mathrm{m}^{-3}$ on ZF2 and ZF3, nearly 6 times smaller than ground levels. Traceable amounts of calcium ions were also observed on both ZF2 and ZF3 filters. We found the sulfate ion concentrations below detection limit $\left(10 \mathrm{ng} \mathrm{m}^{-3}\right)$ on both ZFs as opposed to the high concentration of $950 \mathrm{ng} \mathrm{m}^{-3}$ 
observed on the ground. These preliminary results are consistent with nitrate being an important component of ATAL, as suggested by the model results of $\mathrm{Gu}$ et al. (2016), with the additional presence of some mineral dust aerosol.

How does convection affect the ATAL? CONVECTIVE INFLUENCE ON THE MEASUREMENTS. We assess the influence of convection on the BATAL measurements using a combined approach with trajectory calculations and cloud-top brightness temperature observations from the Himawari-8 geostationary satellite used as a proxy for deep convection. We used an overshooting cloud and anvil detection algorithm described by Bedka and Khlopenkov (2016) to find when and where measurements were likely affected by convection based on back trajectories initialized at the location of balloon measurements (Fig. 11). Figure 12 (bottom) shows back trajectories colored according to their respective altitudes and initialized from the two HFs from Hyderabad (8 and 13 August 2015) between 14 and $18 \mathrm{~km}$ (Fig. 11). Three-dimensional back trajectories were computed using the Langley trajectory model (Fairlie et al., 2014) and meteorological fields from GEOS-5 reanalyses (Rienecker et al., 2008). We show only the trajectories influenced by deep convection during the $72 \mathrm{~h}$ preceding the balloon measurements. The positions of the convective systems are shown with filled red circles. Air masses from the upper troposphere $(\sim 14 \mathrm{~km})$ tend to follow trajectories within the inner core of the Asian anticyclone, while those at higher altitudes follow the edge. The flight on 8 August was likely influenced by regional convection (within $10 \mathrm{~h}$ of the flights) over the Bay of Bengal and along the Indian central and east shores. Brightness temperatures indicate cloud tops reaching the upper troposphere but probably not penetrating the tropopause. Aerosol concentration (Fig. 11), backscatter, and ozone concentration (not shown) increases near 14-16 km may indicate the convective transport of regional Indian pollution and its influence on these measurements. The peak in ozone (not shown) could have been produced via photochemical production due to anthropogenic or lightning-induced nitrogen oxides $\left(\mathrm{NO}_{x}\right)$ emissions.

The peak in aerosol concentration and water vapor (Fig. 9c) near the cold-point tropopause observed on 13 August could have originated from earlier convection over the Bay of Bengal, Thailand, Laos, and south China where trajectories at $\sim 17 \mathrm{~km}$ appear to intersect deep convective systems at these altitudes. However, identifying a specific convective system influencing the measurements is 


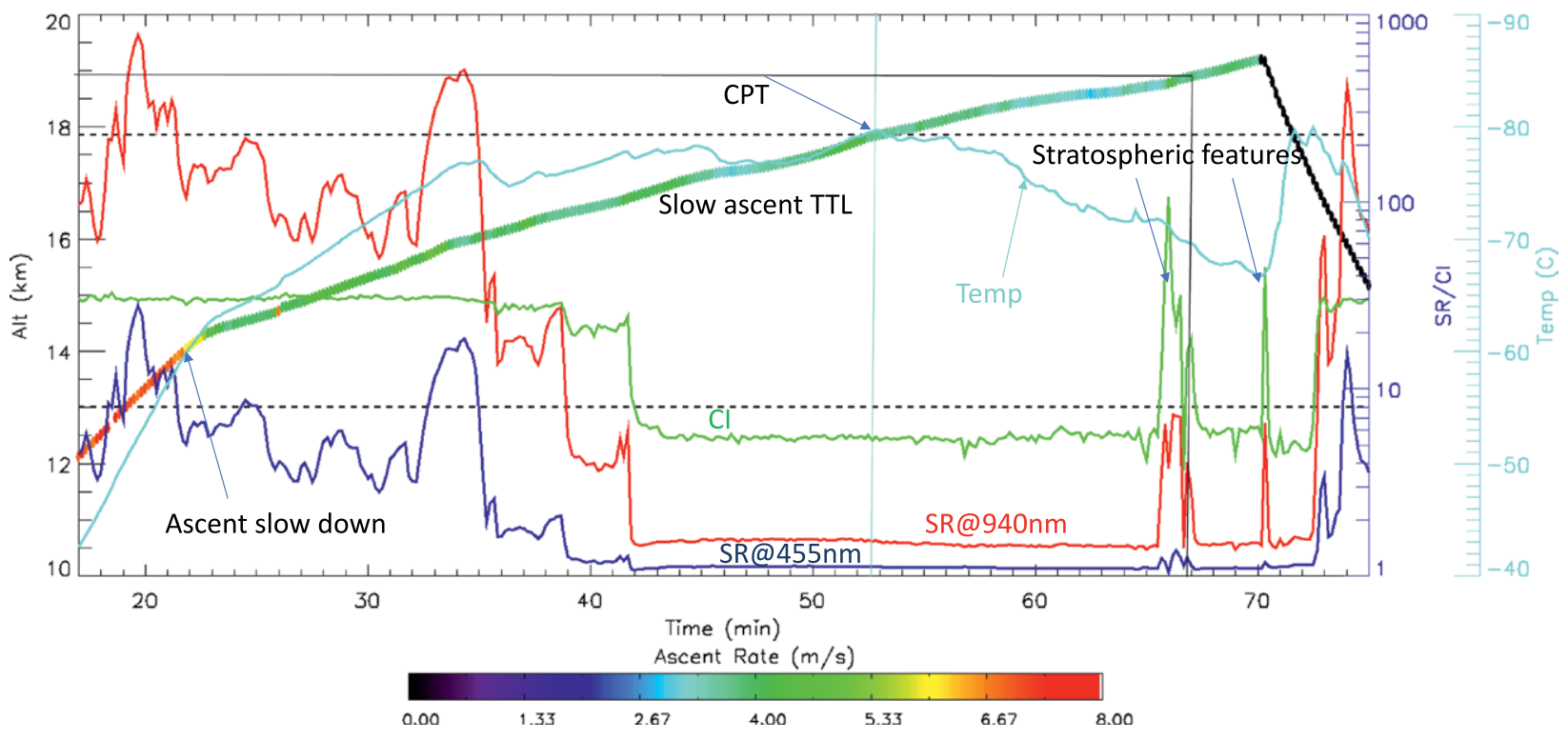

Fig. 13. Altitude, temperature, and scattering ratios at 455 and $940 \mathrm{~nm}$ and $\mathrm{Cl}$ time series along the Boomerang flight launched from Varanasi on 12 Aug 2016.

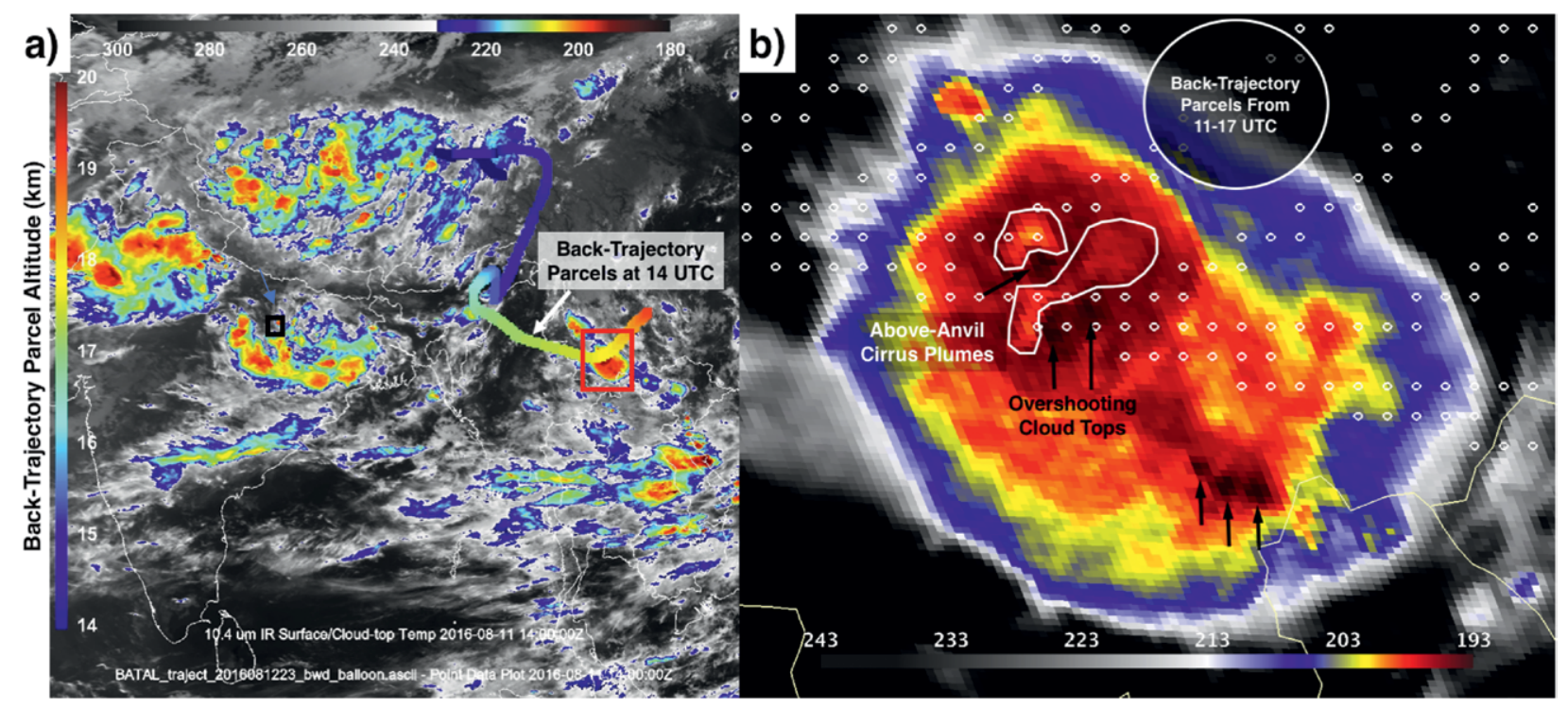

Fig. 14. (a) A Himawari-8 10.4- $\mu \mathrm{m}$ BT image at 1400 UTC II Aug 2016 over Southeast Asia. Back-trajectory air parcels at the time of the image, initialized from balloon flight position launched from Varanasi $32 \mathrm{~h}$ after, colored by their altitude, are overlaid. (b) A zoomed-in image at 1410 UTC over the region outlined by the red box in (a), contrast enhanced to more clearly show OTs (black arrows) and AACPs (white outline), embedded within the anvil of this mesoscale convective system. The locations of back-trajectory parcels above $17.5 \mathbf{~ k m}$ from II00 to 1700 UTC are overlaid with white circles, illustrating the uncertainty in parcel position at the time of the satellite image.

complicated since convection frequently reaches the tropopause during the ASM. It is easier to identify recent and regional MCSs affecting the measurements because of the better accuracy of shorter-trajectory calculations. During the 2016 BATAL campaign, we had a balloon flight in the vicinity of a deep convective system, which will be discussed in the next section.
OVERSHOOT OF ICE PARTICLES IN THE LOWER STRATOSPHERE. We conducted a balloon flight on 12 August 2016 during an active monsoon period using the Boomerang controlled system (see "Description of the BATAL campaigns" section). The time series of temperature, altitude, ascent rate (colored), and COBALD scattering ratios at 455 and $940 \mathrm{~nm}$ are shown in Fig. 13. An 
abrupt decrease in the ascent rate from 6 to $3 \mathrm{~m} \mathrm{~s}^{-1}$ near $14 \mathrm{~km}, 23 \mathrm{~min}$ after the launch, corresponds to the release of the secondary balloon. The valve of the Boomerang system was activated several times to reduce the ascent rate near $1-2 \mathrm{~m} \mathrm{~s}^{-1}$ and to maintain a very slow ascent through the UTLS region. After crossing the cold-point tropopause (at $52 \mathrm{~min}$ ) near $16.5 \mathrm{~km}$ $\left(-80^{\circ} \mathrm{C}\right)$, the system reached the lower stratosphere and sampled layers of elevated SR near $18.5-19 \mathrm{~km}$. COBALD color index values above 10 associated with these stratospheric features indicate the likely presence of ice crystals. We computed back trajectories from the location of the balloon flight to determine if convection could be associated with these layers. Figure 14a shows a Himawari-8 10.4- $\mu$ m cloud-top brightness temperature (BT) image across Southeast Asia overlaid with colored squares corresponding to the position and altitude of back-trajectory air parcels sampled by the balloon $\sim 36 \mathrm{~h}$ later. Air parcels above $17.5 \mathrm{~km}$ intersected an MCS over southeastern China at that time. A zoomed-in image of the MCS (Fig. 14b) shows the presence of overshooting cloud tops (OT; black arrows) and Above-Anvil Cirrus Plumes (AACPs; white outlines). The OTs were persistently generated by this MCS throughout its lifetime, reaching $189-\mathrm{K}$ BT, $4 \mathrm{~K}$ colder than the cold-point tropopause observed by the nearby 1200 UTC sounding from Kunming, China. At the time of this image, AACPs, indicative of injection of ice into the lower stratosphere (Setvak et al. 2010), were being generated by OTs that intersected with the back trajectories. The AACPs radiate at the lower-stratospheric temperature ( $200 \mathrm{~K} ; 18.5-19-\mathrm{km}$ altitude according to the Kunming sounding), which is $10+\mathrm{K}$ warmer than the OT BT. The OT regions to the south had also generated AACPs earlier in the MCS lifetime. Though a 36-h back trajectory has some error, given that this MCS had repeatedly generated AACPs throughout its north-south extent, this MCS is a strong candidate to explain the presence of ice layers in the lower stratosphere observed by the balloon. Other convective storm systems over India during the balloon campaigns have also shown the signature of convection overshooting the cold-point tropopause and reaching the lower stratosphere, providing strong evidence that deep convection during the summer Asian monsoon can influence the lower-stratospheric composition.

DISCUSSION. ATAL and new particle formation. Balloon measurements made from the TIFR balloon facility, Hyderabad, during BATAL strongly suggest that the ATAL is composed primarily of small $(r<0.25 \mu \mathrm{m})$ liquid (mostly volatile, $\sim 80 \%-95 \%)$ aerosol with or without solid cores, correlated with enhanced water vapor and virtually no ozone. Moist layers observed near and above the cold-point tropopause suggest the influence of deep convection, which could also be responsible for transporting aerosol and/or their gas-phase precursors. Up to 100 pptv of $\mathrm{SO}_{2}$ were measured in the eastern part of the Asian anticyclone during the Oxidation Mechanism Observation campaign (H. Schlager 2016, personal communication), suggesting that $\mathrm{SO}_{2}$, as a precursor of sulfate aerosol, can survive convective storms and reach the upper troposphere.

We performed numerical simulations using the microphysical model M7 (Vignati et al. 2004). The aerosol dynamic processes in M7 include nucleation, coagulation, and condensation of sulfuric acid. Aerosol physical properties (size distributions and concentrations) were calculated along back trajectories initialized at the balloon locations and using GEOS-5 meteorological fields. Approximately $100 \mathrm{ppt}$ of $\mathrm{SO}_{2}$ as well as particles (with size distribution corresponding to OPC measurements) were injected at the beginning and along the trajectories when air parcels were influenced by deep convection. Consistent with previous studies (Weigel et al. 2011; Crumeyrolle et al. 2010), sunlight and low temperatures as well as low pressure are favorable to new particle formation. The fast vertical transport, in deep convective storms, of gas-phase aerosol precursors from the surface up to $17 \mathrm{~km}$ is thus highly favorable to nucleation events. Within a few days ( 1.5 days on average), aerosols grow by condensation and coagulation processes from a few nanometers to $100 \mathrm{~nm}$. The extinction coefficients, calculated using a Mie code with a refractive index of 1.521 (representative of ammonium sulfate; Seinfeld and Pandis 2006), ranges from $0.2 \times 10^{-3}$ to $2.4 \times 10^{-3}$ $\mathrm{km}^{-1}$, consistent with CALIOP observations. Moreover, $\mathrm{SO}_{2}$ injected into the model along the transport to simulate the influence of deep convection is found to condense on existing particles, enhancing the extinction coefficients by a factor of 1.5 .

Cloud-aerosol relation in the UTLS. Thin cirrus clouds have been observed very frequently near the coldpoint tropopause during the BATAL campaigns. Coincident OPC/COBALD measurements can be used to investigate ATAL's interaction with clouds. Figure 11 shows the aerosol concentration profiles for particles of radius between 0.094 and $0.15 \mu \mathrm{m}$ measured during the two heavy flights carried out from Hyderabad in 2015. Part of the profiles are colored in red when the CI from COBALD is greater than 10 and indicate the presence of large ice particles also observed through the larger channels of the Wyoming 
OPC (not shown). The concentration of aerosol is very similar on both flights at altitudes above $\sim 18 \mathrm{~km}$, $1 \mathrm{~km}$ above the cold-point tropopause (see arrows). We observe a sharp decrease of aerosol concentration from 10 to $2 \mathrm{~cm}^{-3}$ between 18 and $20 \mathrm{~km}$. We observe a strong variability within the two profiles below $18 \mathrm{~km}$ with a factor of 25 in aerosol concentration between the peaks near 17 (13 August) and $15 \mathrm{~km}$ (8 August) compared to the minimum values near $16 \mathrm{~km}$ on both flights (Fig. 11). The CN measurements during those two flights (not shown) were saturated throughout the troposphere. However, these profiles converge (toward $\sim 20 \mathrm{~cm}^{-3}$ ) near $18-18.2 \mathrm{~km}$ like those shown in Fig. 10 .

We also note that the aerosol minimum observed on 13 August between 15 and $16 \mathrm{~km}$ is associated with the presence of an ice cloud (red) layer as observed by COBALD. In addition, the apparent drop in aerosol concentration near $17 \mathrm{~km}$ on 8 August also coincides with a thin cirrus cloud near the cold-point tropopause. The presence of ice clouds associated with reduction or minimum in aerosol concentration could be consistent with aerosol removal processes such as in-cloud scavenging of aerosol droplets. In contrast, aerosol concentration peaks suggest the presence of a source mechanism. Figure $9 \mathrm{c}$ shows an enhancement of water vapor mixing ratio near 17-18 km coincident with the peak in aerosol concentration on 13 August, also implying that the air masses at these levels were likely influenced by deep convection. Thus, convectively influenced air masses appear to be a source of aerosols up to $1 \mathrm{~km}$ above the cold-point tropopause. Overall, these observations suggest that the aerosol budget is balanced by source and removal mechanisms associated with convection up to $18 \mathrm{~km}, \sim 1 \mathrm{~km}$ above the cold-point tropopause in the monsoon region.

\section{CONCLUSIONS AND PERSPECTIVE. We} provide an overview of the balloonborne activities from India and Saudi Arabia between 2014 and 2017 during the BATAL campaigns. With 68 balloon flights and payloads dedicated to study UTLS aerosols, together with water vapor and ozone sensors, we show the first set of advanced in situ measurements of the ATAL with COBALD backscatter sonde, OPC size distributions, and offline chemical analysis. We found that the ATAL is composed of mostly small $(r<0.25 \mu \mathrm{m})$ liquid $(\sim 80 \%-95 \%)$ aerosols with relatively low SR at $532 \mathrm{~nm}(\mathrm{SR}<1.2)$, consistent with CALIOP satellite observations. Chemical analysis of particles collected near the tropopause indicates the dominant presence of nitrate aerosol with concentration of about $100 \mathrm{ng} \mathrm{m}^{-3}$. Balloon and satellite observations consistently showed a drop in aerosol concentration [CN: $r>10 \mathrm{~nm}$; total and nonvolatile concentrations for $r>94 \mathrm{~nm}$ ] and backscatter near $18 \mathrm{~km}(\sim 400-420 \mathrm{~K}), \sim 1 \mathrm{~km}$ above the cold-point tropopause, and $1-1.5 \mathrm{~km}$ above the $380-\mathrm{K}$ isentropic level. In addition, enhanced water vapor and ice particles have been observed during the BATAL campaigns at and above the cold-point tropopause. These indicate that convection can potentially influence aerosol loadings well above the tropopause level.

The first offline chemical analysis of the ATAL reveals interesting but puzzling results. The presence of nitrate aerosol can be possibly explained by the gasto-aerosol conversion of $\mathrm{HNO}_{3}$ from $\mathrm{NO}_{x}$ produced through lightning or transported by convection from the boundary layer (Gu et al. 2016). However, the undetectable concentration of sulfate ion $\left(<10 \mathrm{ng} \mathrm{m}^{-3}\right)$ seems to be contradictory with the expectation of increasing influence of sulfur emissions in Asia over the past few decades on aerosol trends in the UTLS (Vernier et al. 2015).

Additional observations are needed to address these puzzling questions; $\mathrm{NO}_{x} / \mathrm{NO}_{y}$ measurements would help constrain the role of gas-to-aerosol conversion in the formation of nitrate aerosol. Additional pollution tracers, such as CO, would help to determine the relative importance of in situ lightning production of $\mathrm{NO}_{x}$ versus convective transport from polluted regions to the abundance of nitrate aerosol. In addition, online aerosol mass spectroscopy would help us understand whether volatile aerosols, which would disappear during offline analysis, could be present in the ATAL. A suite of aerosol and ice measurements would contribute to an improved understanding of aerosol-cloud interactions in the UTLS region. To study the impact of the ATAL on heterogeneous ozone chemistry, chlorine monoxide (ClO) and chlorine nitrate $\left(\mathrm{ClONO}_{2}\right)$ would also need to be measured. The BATAL project has been approved to continue for another 3-4 years, and NASA and the Indian Space Research Organisation (ISRO) aim to augment their level of collaboration on this program. Additional balloon payloads will be considered to help address the remaining science questions regarding the composition of the ATAL and its interaction with convection and cirrus clouds. Additionally, the results of the BATAL campaigns will be used to formulate a future NASA-ISRO airborne campaign.

ACKNOWLEDGMENTS. $S$. Kumar is thankful to SERB, New Delhi, for providing him with a National 
Post Doctoral Fellowship (File No: PDF/2015/000691). We thank Drs. J. Kaye, K. Jucks, and R. Eckman at NASA HQ for supporting the BATAL campaigns since 2014 through the UARP and ACMAP programs. We acknowledge technicians and engineers from NARL, TIFR, BHU, and KAUST for their help during BATAL. We also thank the Indian Meteorological Department for providing Doppler weather radar images and MOSDAC for providing INSAT 3D images. We acknowledge Timothy Marvel for his help with making Fig. 1. We also thank Jacquelyn Charity-Hodnett, Syed Mustafa, and Kishore Kumar for their logistical supports.

LABEX VOLTAIRE “Étude des géofluides et des Volatils-Terre, Atmosphère et Interfaces-Ressources et Environnement" (VOLTAIRE; ANR-10-LABX-100-01) is managed by the University of Orléans.

The GEOS-5 data used in this study have been provided by the Global Modeling and Assimilation Office (GMAO) at NASA Goddard Space Flight Center through the online data portal in the NASA Center for Climate Simulation.

We would like to note that Political borders are shown for cursory region identification and may not be accurate.

\section{REFERENCES}

Akhil Raj, S. T., M. Venkat Ratnam, D. Narayana Rao, and B. V. Krishna Murthy, 2015: Vertical distribution of ozone over a tropical station: Seasonal variation and comparison with satellite (MLS, SABER) and ERA-Interim products. Atmos. Environ., 116, 281292, https://doi.org/10.1016/j.atmosenv.2015.06.047.

Bedka, K. M., and K. Khlopenkov, 2016: A probabilistic multispectral pattern recognition method for detection of overshooting cloud tops using passive satellite imager observations. J. Appl. Meteor. Climatol., 55, 1983-2005, https://doi.org/10.1175 /JAMC-D-15-0249.1.

Campbell, P., and T. Deshler, 2014: Condensation nuclei measurements in the midlatitude (1982-2012) and Antarctic (1986-2010) stratosphere between 20 and 35 km. J. Geophys. Res. Atmos., 119, 137-152, https:// doi.org/10.1002/2013JD019710.

Crumeyrolle, S., and Coauthors, 2010: New particle formation events measured on board the ATR-42 aircraft during the EUCAARI campaign. Atmos. Chem. Phys., 10, 6721-6735, https://doi.org/10.5194 /acp-10-6721-2010.

Deshler, T., M. E. Hervig, D. J. Hofmann, J. M. Rosen, and J. B. Liley, 2003: Thirty years of in situ stratospheric aerosol size distribution measurements from Laramie, Wyoming $\left(41^{\circ} \mathrm{N}\right)$, using balloon-borne instruments. J. Geophys. Res., 108, 4167, https://doi .org/10.1029/2002JD002514.
Fairlie, T. D., Vernier, J.-P., Natarajan, M., and Bedka, K. M., 2014: Dispersion of the Nabro volcanic plume and its relation to the Asian summer monsoon. Atmos. Chem. Phys., 14, 7045-7057, https://doi.org/10 .5194/acp-14-7045-2014.

Garny, H., and W. J. Randel, 2016: Transport pathways from the Asian monsoon anticyclone to the stratosphere. Atmos. Chem. Phys., 16, 2703-2718, https://doi.org/10.5194/acp-16-2703-2016.

Gu, Y., H. Liao, and J. Bian, 2016: Summertime nitrate aerosol in the upper troposphere and lower stratosphere over the Tibetan Plateau and the South Asian summer monsoon region. Atmos. Chem. Phys., 16, 6641-6663, https://doi.org/10.5194/acp-16-6641-2016.

Kim, Y.-S., T. Shibata, Y. Iwasaka, G. Shi, X. Zhou, K. Tamura, and T. Ohashi, 2003: Enhancements of aerosols near the cold tropopause in summer over Tibetan Plateau: Lidar and balloonborne measurements in 1999 at Lhasa, Tibet, China. Lidar Remote Sensing for Industry and Environment Monitoring III, U. N. Singh, T. Itabe, and Z. Liu, Eds., Society of Photo-Optical Instrumentation Engineers (SPIE Proceedings, Vol. 4893), 496-503, https://doi .org/10.1117/12.466090.

Komhyr, W. D., R. A. Barnes, G. B. Brothers, J. A. Lathrop, and D. P. Opperman, 1995: Electrochemical concentration cell ozonesonde performance evaluation during STOIC 1989. J. Geophys. Res., 100, 9231-9244, https://doi.org/10.1029/94JD02175.

Kremser, S., and Coauthors, 2016: Stratospheric aerosol-Observations, processes, and impact on climate. Rev. Geophys., 54, 278-335, https://doi .org/10.1002/2015RG000511.

Krotkov, N. A., and Coauthors, 2016: Aura OMI observations of regional $\mathrm{SO}_{2}$ and $\mathrm{NO}_{2}$ pollution changes from 2005 to 2015. Atmos. Chem. Phys., 16, 46054629, https://doi.org/10.5194/acp-16-4605-2016.

Lawrence, M. G., and J. Lelieveld, 2010: Atmospheric pollutant outflow from southern Asia: A review. Atmos. Chem. Phys., 10, 11 017-11 096, https://doi .org/10.5194/acp-10-11017-2010.

Lurton, T., J.-B. Renard, D. Vignelles, M. Jeannot, R. Akiki, J.-L. Mineau, and T. Tonnelier, 2014: Light scattering at small angles by atmospheric irregular particles: Modelling and laboratory measurements. Atmos. Meas. Tech., 7, 931-939, https://doi .org/10.5194/amt-7-931-2014.

Pandit, A. K., H. S. Gadhavi, M. Venkat Ratnam, K. Raghunath, S. V. B. Rao, and A. Jayaraman, 2015: Long-term trend analysis and climatology of tropical cirrus clouds using 16 years of lidar data set over southern India. Atmos. Chem. Phys., 15, 13833 13 848, https://doi.org/10.5194/acp-15-13833-2015. 
Park, M., W. J. Randel, A. Gettelman, S. Massie, and J. Jiang, 2007: Transport above the Asian summer monsoon anticyclone inferred from Aura MLS tracers. J. Geophys. Res., 112, D16309, https://doi .org/10.1029/2006JD008294.

Randel, W. J., and M. Park, 2006: Deep convective influence on the Asian summer monsoon anticyclone and associated tracer variability observed with AIRS. J. Geophys. Res., 111, D12314, https://doi .org/10.1029/2005JD006490.

,,-- L. Emmons, D. Kinnison, P. Bernath, K. A. Walker, C. Boone, and H. Pumphrey, 2010: Asian monsoon transport of pollution to the stratosphere. Science, 328, 611-613, https://doi.org/10.1126/science .1182274 .

Renard, J.-B., and Coauthors, 2016: LOAC: A small aerosol optical counter/sizer for ground-based and balloon measurements of the size distribution and nature of atmospheric particles-Part 1: Principle of measurements and instrument evaluation. Atmos. Meas. Tech., 9, 1721-1742, https://doi.org/10.5194 lamt-9-1721-2016.

Rienecker, M. M., and Coauthors, 2008: The GEOS5 Data Assimilation System-Documentation of versions 5.0.1 and 5.1.0, and 5.2.0. Technical Report Series on Global Modeling and Data Assimilation, M. J. Suarez, Ed., Vol. 27, NASA, 92 pp, https:/gmao .gsfc.nasa.gov/pubs/docs/tm27.pdf.

Rogers, R. R., and Coauthors, 2011: Assessment of the CALIPSO lidar $532 \mathrm{~nm}$ attenuated backscatter calibration using the NASA LaRC airborne high spectral resolution lidar. Atmos. Chem. Phys., 11, 1295-1311, https://doi.org/10.5194/acp-11-1295-2011.

Seinfeld J. H., and S. N. Pandis, 2006: Atmospheric Chemistry and Physics: From Air Pollution to Climate Change. 3rd ed. Wiley, 1326 pp.

Setvak, and Coauthors, 2010: Satellite-observed coldring-shaped features atop deep convective clouds. Atmos. Res., 97, 80-96, https://doi.org/10.1016/j .atmosres.2010.03.009.

Solomon, S., and Coauthors, 2016: Monsoon circulations and tropical heterogeneous chlorine chemistry in the stratosphere. Geophys. Res. Lett., 43, 12 624-12 633, https://doi.org/10.1002/2016GL071778.

Thomason, L. W., and J.-P. Vernier, 2013: Improved SAGE II cloud/aerosol categorization and observations of the Asian tropopause aerosol layer: 19892005. Atmos. Chem. Phys., 13, 4605-4616, https:// doi.org/10.5194/acp-13-4605-2013.
Tobo, Y., Y. Iwasaka, G.-Y. Shi, Y.-S. Kim, T. Ohashi, K. Tamura, and D. Zhang, 2007: Balloon-borne observations of high aerosol concentrations near the summertime tropopause over the Tibetan Plateau. Atmos. Res., 84, 233-241, https://doi.org/10.1016/j .atmosres.2006.08.003.

Venkat Ratnam, M., N. Pravallika, S. Ravindra Babu, G. Basha, M. Pramitha, and B. V. Krishna Murthy, 2014: Assessment of GPS radiosonde descent data. Atmos. Meas. Tech., 7, 1011-1025, https://doi.org/10.5194 lamt-7-1011-2014.

Vernier, J.-P., and Coauthors, 2009: Tropical stratospheric aerosol layer from CALIPSO lidar observations. J. Geophys. Res., 114, D00H10, https://doi .org/10.1029/2009JD011946.

—, L. W. Thomason, and J. Kar, 2011: CALIPSO detection of an Asian tropopause aerosol layer. Geophys. Res. Lett., 38, L07804, https://doi.org /10.1029/2010GL046614.

— , and Coauthors, 2015: Increase in upper tropospheric and lower stratospheric aerosol levels and its potential connection with Asian pollution. $J$. Geophys. Res. Atmos., 120, 1608-1619, https://doi .org/10.1002/2014JD022372.

Vignati, E., J. Wilson, and P. Stier, 2004: M7: An efficient size-resolved aerosol microphysics module for large-scale aerosol transport models. J. Geophys. Res., 109, D22202, https://doi.org/10.1029/2003JD004485.

Vogel, B., and Coauthors, 2016: Long-range transport pathways of tropospheric source gases originating in Asia into the northern lower stratosphere during the Asian monsoon season 2012. Atmos. Chem. Phys., 16, 15 301-15 325, https://doi.org/10.5194/ acp-16-15301-2016.

Vömel, H., D. E. David, and K. Smith, 2007: Accuracy of tropospheric and stratospheric water vapor measurements by the cryogenic frost point hygrometer: Instrumental details and observations. J. Geophys. Res., 112, D08305, https://doi.org/10.1029/2007JD008698.

Weigel, R., and Coauthors, 2011: In situ observations of new particle formation in the tropical upper troposphere: The role of clouds and the nucleation mechanism. Atmos. Chem. Phys., 11, 9983-10 010, https://doi.org/10.5194/acp-11-9983-2011.

Yu, P., and Coauthors, 2017: Efficient transport of tropospheric aerosol into the stratosphere via the Asian summer monsoon anticyclone. Proc. Natl. Acad. Sci. USA, 114, 6972-6977, https://doi.org/10.1073 /pnas.1701170114. 
AMS titles now

available as eBooks

at springer.com

\section{AMS BOOKS}

\section{RESEARCH APPLICATIONS HISTORY}

www.ametsoc.org/amsbookstore

黛 Springer

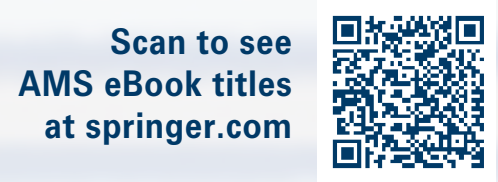

Springer

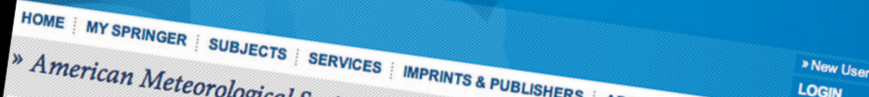

"American Meteorological SOCiety
"AOMTIN

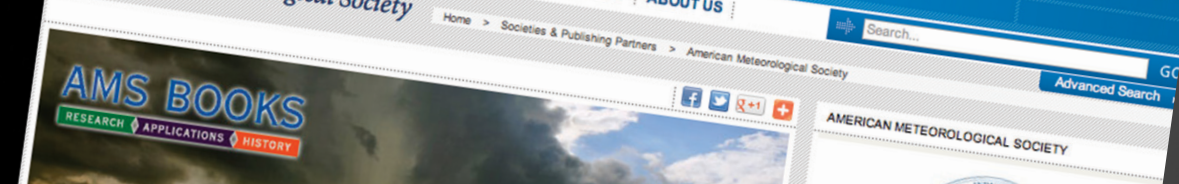

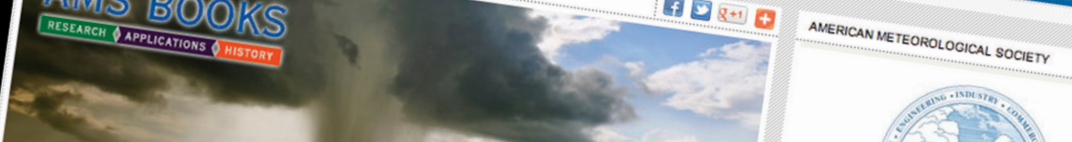

American Meteorol

Promoting the dewerogical Society

the atmos the deverap

the atmospheric and ralent and disseminatb of

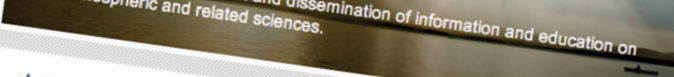

American Meteorological Society eB

AMS Books

published by the AMs a monograph publishing prent

shing program related o ho poer-

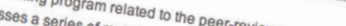

related to the as eBooks) as weil ar ariy out-ortprint vol metoorological and historica journals

to the atmospheric sciences a growing list of academis, which have been urough ographs

ind policy, and general-interest books

Sort listing by:

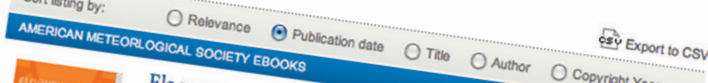

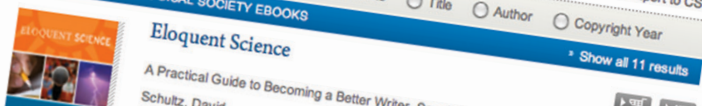

Scholta, David

एक्ष 15

Price from $\$ 45.00$

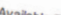

